\title{
20. \\ OD ANARHIZMA DO ŠOVINIZMA: DRUGI SVETSKI RAT I PRIPADNICI AVANGARDNOG UMETNIČKOG KRUGA \\ OKO ČASOPISA ZENIT- LJUBOMIR MICIĆ I MARIJAN MIKAC
}

\section{Goran Miloradović}

\author{
UDK: 009(051)“192“" \\ Izvorni znanstveni članak
}

Sažetak: Prvi svetski rat je iznedrio brojne avangardne umetničke pokrete, koji su nastali iz otpora mladih intelekualaca i umetnika sistemu vrednosti i društvenim strukturama koje su do rata dovele. U članku se kroz analizu biografija i promenjivih ideoloških shvatanja dva člana umetničke grupe zenitista, Ljubomira Micića i Marijana Mikca, istražuju posledice političkih događaja i procesa, a posebno primicanja i izbijanja Drugog svetskog rata na njihove lične odnose i, indirektno, na odnose njihova dva naroda - Srba i Hrvata. Istraživanje je pokazalo da je politička scena, domaća i međunarodna, presudno odredila sudbinu dva bivša prijatelja, koji su, uprkos zajedničkih polaznih levičarskih stavova, živote završili kao nepomirljivi šovinisti.

Ključne reči: zenitizam, Ljubomir Micić, Marijan Mikac, Jugoslavija, Drugi svetski rat, anarhizam, marksizam, internacionalizam, nacionalizam, antisemitizam, fašizam

vaj rad je posvećen analizi uticaja istorijskih zbivanja na promenu ideoloških i političkih shvatanja dvojice intelektualaca i umetnika koji su svoje poznanstvo otpočeli saradnjom u avangardnom časopisu Zenit - Ljubomira Micića i Marijana Mikca.* Tema članka nije časopis Zenit, niti avangardni umetnički pokret zenitizam, a posebno ne njihovo vrednovanje ili tumačenje, nego ideološke, društvene i političke promene kroz koje su ta dva čoveka prošla, od ranih dvadesetih do početka sedamdesetih godina dvadesetog veka. Kao presudan za njihov međusobni odnos biće istražen period uoči Drugog svetskog rata, sam taj rat i, najzad, njegove posledice. Činjenica da su krajem tridesetih godina kontakti 
Micića i Mikca zamrli nije prepreka da se istraži njihovo kasnije pojedinačno delovanje i ideološko i političko pozicioniranje, jer cilj je utvrditi kako su se pod uticajem dolazećeg rata i njegovih efekata njih dvojica promenila u odnosu na vreme Zenita i zenitizma. A promenili su se drastično.

Kada je bio pokrenut, 1921. godine, Zenit se „deklarisao kao ekspresionističko glasilo”. Umetnički pokret zenitizam, koji je tada nastao, njegov osnivač Ljubomir Micić je definisao kao „apstraktni metakozmički ekspresionizam.”2 I u književnoj teoriji je prihvaćeno da je u pitanju ,jedan vid ekspresionizma u jugoslovenskoj književnosti”. ${ }^{3}$ Zaista, zenitizam se javio u vreme kada su ekspresionističke ideje u novoosnovanoj Kraljevini Srba, Hrvata i Slovenaca (SHS) uputile izazov tradicionalnoj kulturi i građanskom društvu, ali se i vrlo brzo transformisao. ${ }^{4}$ Možda najmanje greše oni koji kažu da je Micićev pokret, nastavši iz ekspresionizma, težio da prihvati „dadaističku pobunu” i pripremi tlo „za pretvaranje futurističke drskosti u protonadrealistički bunt posleratne književne avangarde." Zenitizam je u svom manifestu proglasio: „Ekspresionizam, kubizam, futurizam - mrtvi su. (...) Mi smo njihova sinteza ali kao smernica u visinu i reinkarnacija, ${ }^{6}$ a u praksi je zaista pokušao da se realizuje kao sinteza raznih avangardnih struja. ${ }^{7}$ Krajnji ishod, kako je konstatovao Miodrag Protić, trebalo je da bude stvaranje nove balkanske umetnosti. ${ }^{8}$ Pored toga, zenitisti nisu krili ambiciju da odigraju i određenu društvenu ulogu. Tu leži glavni uzrok zle sudbine njihovog lidera.

U centru pažnje ovog istraživanja dve su ličnosti: Ljubomir Micić (1895-1971), srpski književnik, lider i ideolog zenitizma i Marijan Mikac (1903-1972), hrvatski književnik i filmski delatnik, jedan od najvernijih i najupornijih pripadnika zenitističkog kruga. Te dve osobe su izdvojene sa ciljem da se osvetli na koji način su istorijska zbivanja uticala na međusobne odnose srpskih i hrvatskih intelektualaca i umetnika i, indirektno, na odnose njihova dva naroda.

\section{Micić i Mikac: najbolje godine u najgorim evropskim vremenima}

Početak objašnjenja odnosa između političke i estetske sfere u modernom vremenu leži u poslednjim decenijama XIX veka, kada je socijalistička ideološka opcija sadržala potencijal da se razvije u više različitih pravaca. To se dešavalo na širokom talasu demokratizacije, pokrenutom idejama Francuske revolucije, što je dovelo do razvoja nacionalizma i nastanka

\footnotetext{
Радован ВУЧКОВИТ, Модерни правии у књиневности, БеограА 1986., 33. Vučković smatra da je „filozofija zenitizma" bila ekspresionistička, da je njegova pesnička tehnika bila dadaističko-konstruktivistička i da se pokret zalagao za totalnu slobodu izražavanja - sve do anarhije. Isto, 34.

Ljubomir MICIĆ, „Čovek i umetnost”, Zenit, 1/1921., br. 1, 1.-2.

Rečnik književnih termina, Beograd 1992., 940.

O karakteru zenitizma i njegovom odnosu prema ekspresionizmu i dadaizmu videti i: Radomir KONSTANTINOVIĆ, „Četiri pesnika”, Treći program, 4/1972., zima, 182.-183.

Преараг ПАААВЕСТРА, Историја модерне српске кюижевности, БеограА 1986., 501.

' Ljubomir MICIĆ - Ivan GOLL - Boško TOKIN, „Manifest zenitizma”, Авангарда. Свеске за mеорију и историју книжевно/уметничког експеримента, 2/1998.-2000., br. 2-4, Београд 2001., 119.

Na to je Velibor Gligorić ukazao još 1921. Videti: R. KONSTANTINOVIĆ, „Četiri pesnika”, 222.-223.

Navedeno prema: Isto, 245.
} 
masovnih političkih partija u Evropi. ${ }^{9}$ Osim toga, postepeno menjanje društvene i političke klime u evropskim zemljama je brojnim pojedincima omogućilo da iznesu svoje stavove o društvu i njegovom uređenju, tako da se sve češće javljaju glasovi nezadovoljstva i bunta, a neretko su se baš umetnici isticali kao zastupnici novih ideja.

Tako je došlo do toga da su i socijalisti i avangardni umetnici krajem XIX i početkom XX veka bili opozicija građanskom društvu i vlasti. ${ }^{10}$ Lenjin i njegovi saradnici su se u Švajcarskoj kretali upravo u krugovima avangardnih umetnika. ${ }^{11}$ Jedni su bili autsajderi u odnosu na aktuelnu političku vlast, a drugi u odnosu na glavne umetničke tokove. I jedni i drugi su sa društvene margine upućivali svoj izazov centrima moći. I jedni i drugi su se u svom polju delovanja smatrali revolucionarima. Ali, njihovi putevi su mogli ići paralelno jedino dok neka od te dve kolone ne stigne do svog cilja - dok se ne etablira. Tada su se ti putevi morali ili poklopiti, ili razići. Uostalom, reklo bi se da nije bez značaja činjenica da Marks i Engels, koji su i inače bili vrlo suzdržani prema umetnosti, nisu pokazivali nikakvu naklonost ka umetničkoj avangardi. ${ }^{12}$ To je logično, jer su avangardni umetnici bili neka vrsta konkurencije revolucionarima.

Takvo poreklo i društveni karakter avangardne umetnosti uslovili su da ti umetnici pokažu snažne simpatije ka ideji političke pobune, a neretko i sklonost prema ideologijama anarhizma i/ili marksizma. Iz tog semena rođena je moderna umetnost: ponekad lična i emotivna, ponekad jasno politički angažovana, ali uvek subverzivna, izazivačka i borbena. Kakav će efekat to imati po same umetnike zavisilo je od konkretnih političkih okolnosti.

Kada je reč o Miciću i Mikcu, njima je zapalo da najbolje godine svojih života prožive kada je Evropa doživljavala najgore: dva svetska rata, različiti autoritarni i totalitarni režimi, ekstremne ideologije, populizam, građanski ratovi, masovni zločini, genocid i, posle svega toga, dugotrajna podeljenost kontinenta gvozdenom zavesom. Njih dvojica su izdvojeni između brojnih drugih intelektualaca, jer se može pratiti dugogodišnji razvoj njihovih međusobnih odnosa, paralelno sa uticajem koji su na njih vršila politička zbivanja. Posle zajedničkog početka javnog života u krugu saradnika Zenita, istorijske okolnosti su vodile Micića i Mikca na sasvim različite strane i, istovremeno, daleko od umetničkog stvaranja koje je obeležilo njihovu mladost. Oni nisu odoleli iskušenjima „vremena netrpeljivih”.13

\section{Dve biografije $\mathrm{u}$ istorijskom kontekstu}

Vreme zenitizma. Najznačajniji period njihovog delovanja na polju kulture i društvenih odnosa bilo je pet godina dok je izlazio časopis Zenit: 1921-1926. Tada Micić i Mikac deluju maksimalno saglasno, a postepeno njihov odnos starijeg i mlađeg, obožavanog i nepri-

\footnotetext{
Fransoa FIRE, Prošlost jedne iluzije. Komunizam u dvadesetom veku, Beograd 1996., 30.

10 Eric HOBSBAWM, „Socialism and the Avant-Garde, 1880-1914”, Uncommon People. Resistance, Rebellion and Jazz, London 1998., 171.-172.

11 Rade LEPOSAVIĆ, „DADA Clipping. Traganje za izgubljenim srpskim (?) dadaistom”, New Moment-New Ideas, 15/2001., 22.

12 E. HOBSBAWM, „Socialism and the Avant-Garde”, 173.

13 O okolnostima u tadašnjoj Evropi: Андреј МИТРОВИЋ, Време нетрпељивих. Политичка историја великих држава Eвpone 1919-1939, Подгорица 1998.; Balkan Strongmen: Dictators and Authoritarian Rulers of South Eastern Europe, (Ed. Bernd J. Fischer), London 2007.; Stephen LEE, European dictatorships 1918-1945, London - New York 2000.
} 
Slika 1. Anuška i Ljubomir Micić u redakciji Zenita u Beogradu 1924. godine

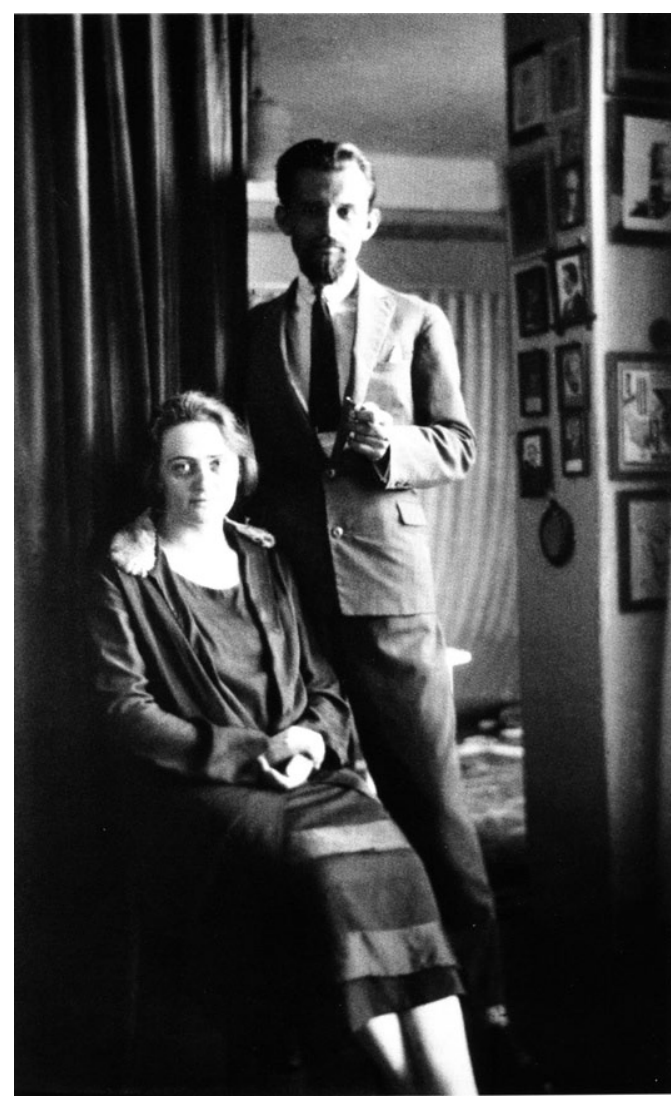

kosnovenog lidera i požrtvovanog sledbenika, prerasta u odnos dvojice ravnopravnih saradnika i prijatelja. ${ }^{14} \mathrm{U}$ prvo vreme Micić je bio bolje situiran: mogao je redovno da izdaje časopis i zenitističku biblioteku. ${ }^{15}$ Istovremeno, Mikac se borio za golu egzistenciju. Kao zenitisti obojica su nepoželjni, kako u očima vlasti, tako i u intelektualnim krugovima. Politički konflikti i odbacivanje sredine u kojoj deluju (Mikac u Petrinji, a Micić u Zagrebu), maksimalno su im suzili polje delovanja. Iritiran provokativnom retorikom lidera HSS-a Stjepana Radića Micić je napisao ostrašćen članak na temu hrvatske kulture. ${ }^{16} \mathrm{Zbog}$ toga mu je, navodno, pretio i sam Radić, tako da „(p)od pritiskom histerije, koja je obuzela $\mathrm{Za}$ greb, Ljubomir Micić, nezaštićen i osamljen kao uvek, beži u Beograd". ${ }^{17}$ Redakcija Zenita je u Beograd preseljena 1923. godine, na adresu Obilićev venac 36.

Micić tu, u znatno lošijim materijalnim uslovima, istrajava u svojim opredeljenjima i ambicijama, po cenu odricanja od svega drugog. ${ }^{18}$ Istovremeno, otpor zenitizmu, koji iritira i prestoničko građanstvo i političke faktore, kontinuirano stiže i iz krugova umetnika i iz državnih institucija. Časopis je izlazio još tri godine, sve dok Micić nije bio prisiljen da se i odatle seli, jer mu je zbog sadržaja poslednjeg broja Zenita, s jedne strane pretilo hapšenje i zatvor, a s druge je dobijao anonimne pretnje, što je ugrožavalo i njegov fizički

14 Brojni izvori to pokazuju: Narodna biblioteka Srbije (dalje: NBS), Ljubomir Micić, rukopisi (dalje: LjMR). Prepiska M. Mikca i Lj. Micića je objavljena: Видосава ГОАУБОВИЋ, „Из преписке око Зенита и зенитизма”, Љетопис Српског културног друштва „Просвјета”, 4/1999., 277.-293.; 5/2000., 231.-258.; 6/2001., 237.-256.; 7/2002., 178.204.; 8/2003., 305.-318.; Видосава ГОАУБОВИЋ, „Преписка између Маријана Микца и Фубомира Мицића (1931.)", Бетопис Српског културног друштва „Просвјета”, 9/2004., 400.-408.; 10/2005., 369.-383.

15 Branimir DONAT, „Performans kao oblik komunikacije hrvatske DADE i njenih inačica s javnošču”, Dani Hvarskoga kazališta. Grada i rasprave o hrvatskoj književnosti i kazalištu, 30/2004., br. 1, 7.-8. Zenit je redovno izlazio samo u periodu 1921-1923, kada ga je, kako se smatra, finansirala Micićeva bogata tazbina, vlasnici fabrike papirne galanterije Lipa Mill u Zagrebu. Međutim, mnogi autori se ne bi složili sa B. Donatom da je zenitizam bio varijanta dadaizma, kako se može razumeti iz njegovog članka. A pitanje je i da li su „zenitističke večernje” zaista bile „performansi”...

16 Ljubomir MICIĆ, „Papiga i monopol 'hrvatska kultura”, Zenit, 3/1923., br. 24, 1.-2.

17 УРЕАНИШТВО ЗЕНИТА, „Фимм јеАног књижевног покрета и јеАне Ауховне револуције”, Зенит, 6/1926., br. 38, [33].

18 Micićev saradnik Mihajlo S. Petrov kasnije se sećao: „Nešto što nikad neću moći da zaboravim (...) bila je njegova požrtvovanost. (...) Pamtim kad su Micić, njegova žena i jedan vučjak, ovoliki, koji bi sam mogao da pojede kilo mesa, ručali zajedno kod Moskve (jer, situacija je bila takva da je on pare ulagao u Zenit) po jednu belu kafu, njih dvoje, i tri zemičke. Sad možete misliti koliko je onaj ker bio sit od toga.” R. LEPOSAVIĆ, „DADA Clipping”, 13. 
integritet. ${ }^{19}$ Povod za konačni obračun sa Zenitom pružilo je objavljivanje članka „Zenitizam kroz prizmu marksizma”, a kap u već prepunu čašu su dolile zenitističke demonstracije protiv nobelovca Rabindranata Tagore tokom njegovog javnog predavanja 15. novembra 1926. u Beogradu. ${ }^{20}$ Beogradski intelektualni i politički krugovi taj skandal im nisu oprostili, a Politika je razdraženo pretila da će „svakako škoditi ugledu naše policije, ako ove izgrednike ne nauči redu i pristojnosti." ${ }^{21}$ Zenit je zabranjen, a Micić je u decembru 1926. preko Italije emigrirao u Francusku. Širi krug saradnika Zenita se i pre toga rasuo, Micićev brat Branislav (Ve Poljanski) je još 1925. otputovao u Pariz, gde su mu se uskoro pridružili sekretar redakcije Vladimir Skerl, Ljubomir Micić i njegova supruga Anuška. ${ }^{22} \mathrm{U}$ to vreme, od najužeg jezgra zenitista u Jugoslaviji je ostao još samo najmlađi član - dvadesettrogodišnji Marijan Mikac.

Posle zenitizma, a pre rata. Ali, vođa zenitista se ni tada nije predavao - pravio je planove da iz inostranstva pokrene novo zenitističko glasilo. Već u januaru 1927. Micić je preko svoje supruge saopštio Mikcu da njemu prepušta „dužnost” kada i ona bude napustila zemlju. Ta „dužnost” je podrazumevala dalji rad redakcije časopisa (ali pod drugim nazivom), a u jednom pismu Mikac kaže da bi time „pitanje njegovog položaja i slobode rada bilo rešeno, a uveren sam - i pitanje dalje zenitističke akcije u ovoj zemlji - naravo, po Vašem odobrenju i pod Vašom kontrolom." ${ }^{33}$ Taj predlog, iako nije realizovan, svedoči o velikom poverenju koje je u to vreme Micić gajio prema Mikcu. ${ }^{24}$ Sa druge strane, o Mikčevoj privrženosti harizmatičnom Miciću možda najviše govori činjenica da je u jesen 1927. svom prvorođenom sinu dao ime Ljubomir. ${ }^{25}$ Uprkos naporima, zenitizam je Micićevim odlaskom završio svoje delovanje. Mikac je tada, uprkos svojim mnogo puta iskazanim željama, prestao da stvara kao zenitista, okrenuvši se građanskoj svakodnevici: oktobra 1927. zaposlio se kao službenik u Tvornici vunenih tkanina Koste Ilića u Beogradu, a kasnije u njenom odeljenju u Turnju kod Karlovca. ${ }^{26} \mathrm{U}$ jednom pismu Miciću on kaže:

Ne pišem ništa, niti imam vremena za privatan rad. Osam sati dnevno u kancelariji, radi se i subotom posle podne (...) Ono nekoliko časova što ih provodim kod kuće zauzet sam kućnim poslovima. Moram da pomognem ženi, ako ništa drugo: barem dete da pridržim (...). ${ }^{27}$

Polako, ali sigurno, Mikac je tonuo u živo blato građanskih konvencija, brinući, pored toga, brige porodične svakodnevice. Istovremeno, u periodu od 1927. do 1936. Micić je

19 Видосава ГОАУБОВИЋ, „Из преписке око Зенита и зенитизма (1927)”, Һетопис СКА „Просвјета”, 6/2001., 252.; Зоран МАРКУШ, Зенитизам, БеограА 2003., 36.

20 Autor članka o zenitizmu i marksizmu je, najverovatnije, sam Micić. Videti: М. РАСИНОВ, „Зенитизам кроз призму марксизма”, Зенит, 6/1926., br. 43, 12.-15.; „Тагоре и зенитистичке Аемонстрације”, Зенит, 6/1926., br. 43, 15.-16.; Бранко Ве ПОААНСКИ, Һубомир МИЦИТ, „Отворено писмо Рабиндранат Тагори”, Зенит, 6/1926., br. 43, 17.-19.; 3. МАРКУШ, Зенитизам, 22.

21 „Београђани одушевьено поздравими великог индиског песника”, Политика, br. 6669, 17. 11. $1926 ., 6$.

22 Branislav SKROBONJA, „Hasta la vista ili priča o Miciću”, New moment, 4/1995., 22. Skrobonja je upoznao Micića 1962. ili 1963, družio se s njim godinama i organizovao njegovu sahranu. Skrobonjina sećanja su dragocena za rekonstrukciju Micićeve biografije u posleratnom periodu, za koji ima malo izvora.

23 NBS, LjMR/II/2, Pismo Mikca Miciću, Petrinja 26. 1. 1927.

24 Pored toga, prema svedočenju V. Skerla, kompletna ostavština Micića i Zenita bila je poverena na čuvanje Mikcu. Prema: B. SKROBONJA, „Hasta la vista”, 22.

25 U pismu otkucanom na pisaćoj mašini ime Mikčevog sina je istaknuto velikim slovima, čime je želeo da Miciću skrene pažnju na svoj gest. NBS, LjMR/II/2. Pismo Mikca Miciću, Beograd 14. 12. 1927.

26 Борис ВРГА, „Зенитистичке вечерње у Петрињи”, Һетопис СКА „Просвјета”, 10/2005., 385. (nap. 2).

27 NBS, LjMR/II/2. Pismo Mikca Miciću, Beograd 4. 6. 1928. 
u otadžbini bio sasvim marginalizovan kao stvaralac. Ono što je objavio izašlo je na francuskom jeziku, u Parizu, dok je u Jugoslaviji štampao samo nekoliko priloga u ljubljanskoj reviji Tank. ${ }^{28}$ Međutim, tokom tridesetih godina u životu njegovog prijatelja došlo je do važnih promena. Mikac je počeo da se bavi unosnim poslom uvoza i distribucije američkog filma (za Fox 1929-1931, za Paramount posle 1931), uređuje filmske revije i učestvuje u proizvodnji Paramount-ovih filmskih žurnala za Jugoslaviju, a krajem tridesetih ima i svoju firmu za plasman američkog stripa. ${ }^{29}$ Time je on rešio svoje egzistencijalne probleme, ali je ujedno i definitivno odustao od avangardnog delovanja u umetnosti. Početkom 1931. pisao je Miciću: „Poslije smrti 'Zenita' i ja sam za literaturu umro.” ${ }^{30}$ Došavši do solidnih prihoda i zanimljivog posla Mikac se, ipak, sa čežnjom sećao uzbudljivog vremena umetničke avangarde, a u jednom pismu je izrazio želju da njegov sin nastavi tamo gde je on stao. ${ }^{31} \mathrm{U}$ prvoj polovini tridesetih godina Mikac je već bio u poziciji da Miciću (koji je bio u Parizu) omogući honorarni posao prevođenja filmskih žurnala sa francuskog na srpski, kako bi ublažio svoje materijalne nedaće. ${ }^{32}$ Kada se Micić, posle deset godina izgnanstva, 1936. vratio u Jugoslaviju, prostor za delovanje bio mu je maksimalno sužen, a društveno-politička klima bitno promenjena. $S$ druge strane, oslobodivši se stalne borbe za golu egzistenciju, Mikac se ponovo okreće literaturi, ali ne više avangardnoj. On tada počinje da piše u sasvim drugom duhu. Moguće je da nije puka koincidencija to što je poslednje sačuvano Mikčevo pismo Miciću, kratko i kurtoazno, datirano 27. maja 1938, ${ }^{33}$ nedugo posle objavljivanja Mikčevog „satiričnog romana” Doživljaji Morica Švarca u Hitlerovoj Njemačkoj. Nema dokaza da su i kasnije održavali kontakt: u Micićevoj zaostavšitini ima prepiske i posle 1938, ali nema više ni jednog Mikčevog pisma. Micić je do napada na Jugoslaviju uspeo da objavi samo jedan broj novog „književno-političkog” časopisa Srbijanstvo, koji je odmah bio zabranjen. ${ }^{34} \mathrm{U}$ obrazloženju odluke Ministarstva unutrašnjih dela pisalo je „da se taj broj zabranjuje zbog šovinističkih ideja i raspaljivanja nacionalne mržnje." ${ }^{35} \mathrm{~S}$ obzirom da je to bilo vreme nemačke invazije na zemlje Beneluksa i Francusku, verovatno je i međunarodna situacija pospešila zabranu. Poslednje što je vlastima Jugoslavije trebalo u trenutku kada gube glavni spoljnopolitički oslonac bilo je dalje zaoštravanje međunacionalnih odnosa. Posle toga Micić se potpuno pasivizovao i sa suprugom živeo povučeno u svom stanu u Beogradu, u Njegoševoj ulici 69. Tu ih je zatekao rat.

Ratno vreme. Ne kaže se slučajno: dok jednom ne smrkne drugome ne svane. Period novog svetskog rata otvorio je Mikcu mogućnost da dosegne vrhunac karijere. Od marginalca na kulturnoj i društvenoj sceni koji je, tražeći ma kakav posao, lutao između Senja,

28 Izašla su svega dve sveske Tanka 1927: br.1 i br. 11²-3. Treća je već bila zabranjena. В. ГОАУБОВИЋ, „Из преписке око Зенита и зенитизма” (1928-1929), Һетопис CKА „Просвјеmа”, 7/2002., 186. (nap. br. 4).

29 Mikčevo preduzeće Press Service $M M$ imalo je sedište na Pantovčaku 128. Videti: NBS, LjMR/II/2. Pismo Mikca Miciću, Berlin 9. 11. 1931; Pismo Mikca Miciću, Zagreb 27. 5. 1938; Ivo ŠKRABALO, 101 godina filma u Hrvatskoj 1896.-1997.: Pregled povijesti hrvatske kinematografije, Zagreb 1998., 120.; Вилосава ГОАУБОВИТ - Ирина СУБОТИТ, Зенит 1921-1926, Београх 2008., 342.

30 NBS, LjMR/II/2. Pismo Mikca Miciću, Berlin, 9. 11. 1931.

31 NBS, LjMR/II/2. Pismo Mikca Miciću, Berlin, 19. 11. 1931.

32 NBS, LjMR/II/2. Pismo Mikca Miciću, Zagreb 14. 11. 1933.; Pismo Mikca Miciću, Zagreb 1. 12. 1933.; Telegram direktora Paramount-ovog predstavništva u Francuskoj F. L. de Blois-Lieach Miciću, Saint-Maurice 7. 3. 1935.

33 NBS, LjMR/II/2. Pismo Mikca Miciću, Zagreb 27. 5. 1938.

34 Србијанство. Книжевно-политички часопис, 1/1940., br. 1.; NBS, LjMR/II/2. Pisma i dopisnice uredništvu u periodu 25. 5. 1940.-6. 1. 1941 .

35 B. SKROBONJA, „Hasta la vista”, 17. 


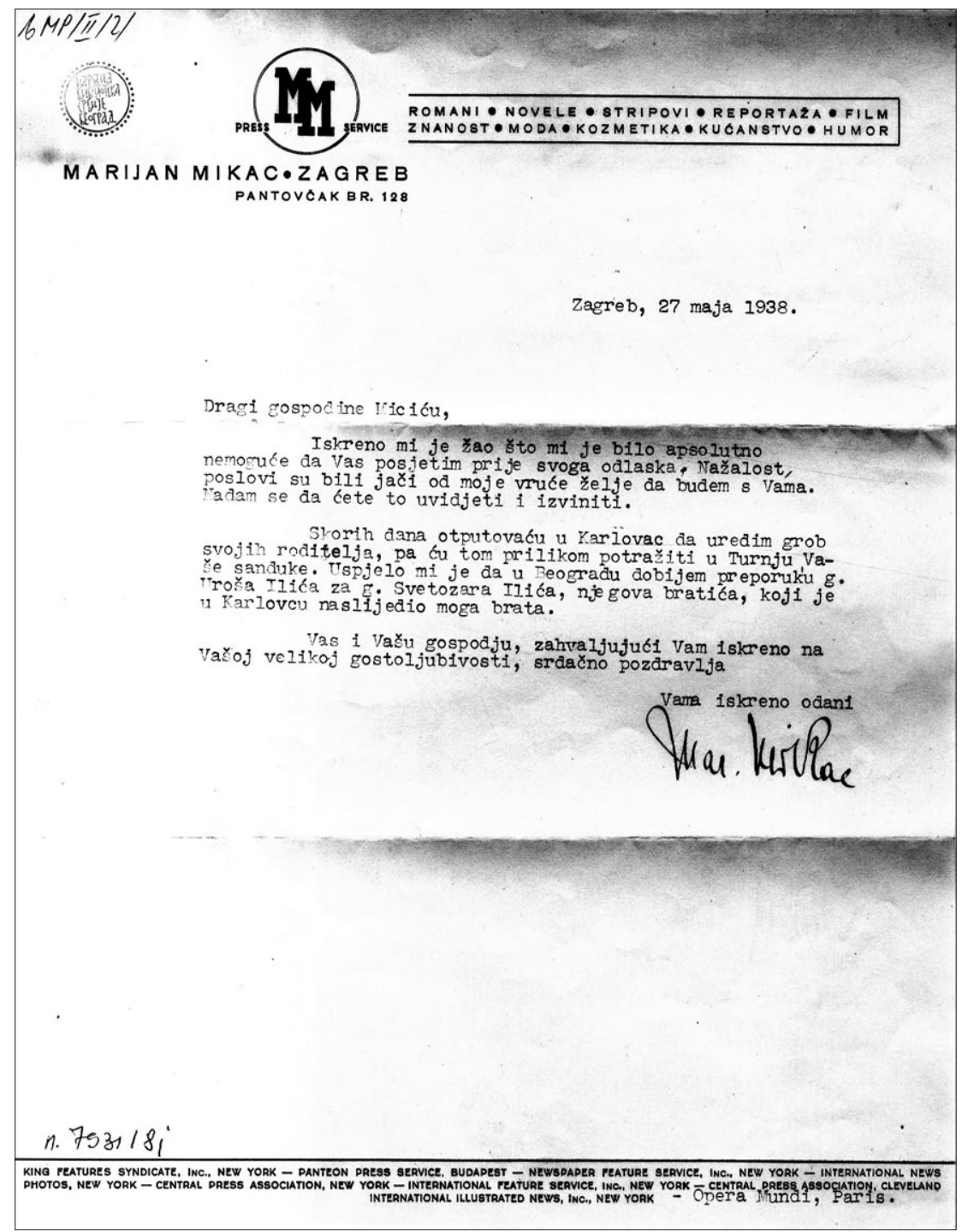

Slika 2. Zadnje poznato pismo Marijana Mikca Ljubomiru Miciću. Zagreb, 27. svibnja 1938.

Petrinje, Sarajeva, Beograda, Karlovca, Zagreba i dunavskih brodova, postao je nešto značajno: 26. I 1942. imenovan je za upravnika (ravnatelja) Hrvatskog slikopisa, filmske kuće Nezavisne Države Hrvatske. ${ }^{36}$ Mikac se u novoj ulozi dobro snašao, a u istoriji filma u Hrvatskoj ostalo je zapisano:

Njegovi suradnici u vrijeme rata nisu ga smatrali aktivnim ustašom (...) ali je svakako uživao povjerenje ustaških vlasti. On je praktički sam održavao vezu s višim organima političke kontrole, tako da su ljudi okupljeni u poduzeću mogli relativno neometano obavljati svakodnevne poslove, pa čak i progurati filmove koji su bili politički neutralni. ${ }^{37}$ 
Pod njegovim rukovodstvom novoosnovana filmska kuća je postigla određene uspehe. Snimljeni su dokumentarni film Barok u Hrvatskoj (Oktavijan Miletić, 1942), desetak kratkometražnih filmova, dugometražni igrani film Lisinski (Oktavijan Miletić, 1944), propagandni film Straža na Drini (Branko Marjanović, 1942) dobio je bronzanu medalju na Filmskom festivalu u Veneciji 1943, a redovno su snimani filmski žurnali (preko 200), sve do maja 1945. godine. Pored toga, Mikac je napisao brošuru o Hrvatskom slikopisu. ${ }^{38}$ Prilikom oslobođenja Zagreba, dok su pristalice ustaša bežale ka Zapadu - Mikac je ostao. Iako je kao rukovodilac važne institucije bio uhapšen - nije mu suđeno. ${ }^{39}$ Mirko Lukavac, koji je 1945. preuzeo rukovođenje filmskom proizvodnjom u Zagrebu, kasnije je zapisao u svojim sećanjima: „Kompromitirani funkcioneri su pobjegli, a ostalo osoblje smo preuzeli." ${ }^{\prime \prime 0}$ Mikac, koji je bio „funkcioner”, a ne „osoblje”, nije preuzet. On kao da je postao nevidljiv komunističkim vlastima. ${ }^{41} \mathrm{Za}$ to se pobrinuo sekretar izaslanika Svete stolice kod hrvatskog Episkopata, Đuzepe Masuči (Giuseppe Masucci, 1906-1964), o čemu svedoči njegov dnevnik:

28. lipnja [1945]. U 11.30 me je posjetio predsjednik vlade Bakarić. (...) Toplo sam mu preporučio bivšeg ravnatelja za film Marijana Mikca, koji je u tamnici. ${ }^{42}$

Preporuka je urodila plodom, a kada je kasnije sa porodicom napustio Jugoslaviju (verovatno 1947), Mikac je prvo utočište našao u italijanskom manastiru Montevergine, kod Masučija. ${ }^{43}$ Sasvim drugačije prošao je Ljubomir Micić. Ratne godine za njega su značile konačni gubitak svih, pa i najneznatnijih mogućnosti da javno deluje. $S$ obzirom da je njegova supruga Anuška bila Jevrejka (koja je udajom prešla u pravoslavlje), Micići su bili pod stalnom pretnjom hapšenja i logora. Verovatno im je pomoglo to što se u Beogradu nije znalo za njeno poreklo, jer je Anuška rodom bila iz Vinkovaca, tokom tridesetih godina je uglavnom živela u inostranstvu, a sa jevrejskom opštinom u Beogradu nije se povezala. ${ }^{44}$ Kada je, najzad, došao trenutak oslobođenja od okupatora, postalo je jasno da sloboda nije bila namenjena svima. Micićeva društvena pozicija nije se, u suštini, promenila ni posle rata - iako je, za razliku od Mikca, on novim vlastima bio i te kako vidljiv:

Kada je Micić posetio ministra kulture Vladu Ribnikara i tražio potvrdu da je književnik, kako bi sačuvao stan, rečeno mu je da u novom društvu nema mesta za zenitizam, a potvrda mu je uskraćena. ${ }^{45}$

I. ŠKRABALO, 101 godina filma u Hrvatskoj, 120. Nejasno je šta znači izraz „aktivni ustaša” i na čemu se zasniva podela na „aktivne” i ostale. O Mikčevim političkim uverenjima govori njegov posleratni „aktivizam”.

38 Marijan MIKAC, Tri godine rada Hrvatskog slikopisa, Zagreb [1944.]

39 Tko je tko u NDH, 270.-271.; I. ŠKRABALO, 101 godina filma u Hrvatskoj, 120.

40 Mirko LUKAVAC, „Prvi dani kinematografje u SR Hrvatskoj (1945-1946)” Filmska kultura, 19/1975., br. 100, 165.

41 O Mikcu i Lukavcu opširnije: Горан МИАОРААОВИЋ, „Аомаћи трилери у иностраној режији: Обавештајне и саботерске активности против југословенске кинематографије 1945-1955. године", Годшиъак за друштвену ucmopujy, 17/2010., br. 1, 67.-88.

42 Giuseppe MASUCCI, Misija u Hrvatskoj 1941-1946, Madrid 1967., 209.

43 Marijan MIKAC, „Predgovor”, u: Giuseppe MASUCCI, Misija u Hrvatskoj, 22. Mikac i Masuči su ostali u prisnom kontaktu i posle rata.

44 Jedan od retkih ljudi u Beogradu, koji su znali njeno poreklo, bio je Vladimir Skerl (1899-1981), nekadašnji sekretar i prevodilac redakcije Zenita. Potpisivao se i kao Skerlić. Tokom rata radio je u aparatu Nedićeve vlade, pa je možda uticao da Micići tada budu neprimećeni. Posle rata je osuđen na osam godina zatvora. Videti: Jevrejski istorijski muzej, Beograd, Kartoteka članova; B. SKROBONJA, „Hasta la vista”, 21.-23.; 3. МАРКУШ, Зенитизам, 37.; В. ГОАУБОВИЋ - И. СУБОТИЋ, Зенит, 369.-370.

45 Zoran MARKUŠ, „Razgovori sa Ljubomirom Micićem, 3.”, Odjek, 24/1971., br. 22, 21. 
Vladislav Ribnikar je pre rata bio direktor dnevnika Politika (koja je preporučivala policiji da zenitiste „nauči redu”), a posle rata ministar i predsednik Komiteta za kulturu i umetnost Vlade FNRJ. Sa Anuškom, brojnim umetničkim delima, knjigama i dokumentacijom o svom radu Micić je iz trosobnog stana u Njegoševoj ulici 69 prisilno iseljen u garsonjeru dimenzija približno $3 \times 8$ metara, na poslednjem, petom spratu zgrade u ulici Prote Mateje 18 u Beogradu. ${ }^{46}$ Time je on bio materijalno uništen i potpuno marginalizovan. Duboke društvene i političke promene bacile su u zaborav njegovo delovanje u međuratnom periodu. ${ }^{47}$

Posle rata. U novim okolnostima i Micić i Mikac su se našli van glavnih društvenih i kulturnih zbivanja: Mikac kao politički emigrant, a Micić kao unutrašnji emigrant. Međutim, posle rata su, osim Ribnikara, na vlast došli i drugi Micićevi stari neprijatelji, među kojima se nalazio i najuticajniji - Miroslav Krleža. ${ }^{48}$ Pre Drugog svetskog rata Micić je Krležu u svom časopisu nazivao „Mimostav Krpeža”, ${ }^{49}$ tvrdio da je on „uobrazio da je revolucionaran i komunistički pisac”, ${ }^{50}$ njegov rad osporavao kao „feljtonizam” ${ }^{51}$ i nazivao „domobranskom književnošću", ${ }^{52}$ a ni posle rata o njemu (a ni o Krklecu ${ }^{53}$ ) nije imao da kaže ništa lepo, već jedino: „pokvarenjak, srbožder, ustaša”. ${ }^{54} \mathrm{~A}$ upravo sa Krležom su bili bliski beogradski nadrealisti, naročito Marko Ristić, čija „otvorena netrpeljivost” prema Miciću je bila dobro poznata. ${ }^{55}$ Te okolnosti su, mnogo godina kasnije, navele jednog istraživača da u vezi zenitizma konstatuje:

Dugogodišnje prećutkivanje toga pokreta skoro da ima odlike zavere. (...) Najverovatnije je u pitanju spoj stvaralačke taštine i društvene moći pojedinih umetnika koji su hteli da $\mathrm{u}$ istoriji ostanu prvi i jedini predstavnici naše avangarde. Jer, među nadrealistima bilo je pisaca oda, ambasadora i generala. ${ }^{56}$

Izolovan i odbačen, Micić je svoje poslednje decenije živeo u oskudici i krajnje neprijateljskom okruženju, upućen jedino na suprugu, u zgradi čiji stanari su ga maltretirali. Jedina komunikacija koju je održavao bilo je dopisivanje sa pojedinim emigrantima, ali mu je pošta kontrolisana, a ponekad i oduzimana. Micić posle rata nije radio, jedino je Anuška neko vreme bila zaposlena kao inokorespondent. ${ }^{57}$ Nisu imali penziju niti socijalnu ili zdravstvenu zaštitu. Micić se izdržavao od prodaje gume za žvakanje, kafe i hemijskih olovaka koje su mu iz inostranstva slali retki preostali prijatelji, Anuškini rođaci i Crkvena

\footnotetext{
Z. MARKUŠ, „Razgovori sa Lj. Micićem, 1.”, Odjek, 24/1971., br. 20, 20.

В. ГОАУБОВИЋ - И. СУБОТИЋ, Зенит, 350.

48 O Krležinom uticaju u socijalističkoj Jugoslaviji videti: Горан МИАОРААОВИЋ, Аепота под надзором. Совјетски културни утичаји у Југославији 1945-1955, Београд 2012., 106., 114.-115., 154.-157., 306.-309.

49 Ljubomir MICIĆ, „Revolucija u gradu belome”, Zenit, 1/1921., br. 10, 3. Misli se na grad Zagreb.

50 Бубомир МИЦИЋ, „Аегенда о мртвом покрету или између зенитизма и антизенитизма”, Зенит, 6/1926., br. 43,8 .

51 „Domaća zadaća”, Зенum, 2/1922., br. 17-18, 59.

52 УРЕАНИШТВО ЗЕНИТА, „Фимм јеАног књижевног покрета”, [28, 34.$]$

53 Za Krkleca se u Zenitu tvrdio da je plagijator. Videti: „Opet plagijat”, Zenit, 2/1922., br. 12, [korice]; UREDNIŠTVO ZENITA, „Netužni nekrolog 1922. godini”, Zenit, 2/1922., br. 19-20, 68.

54 Prema: B. SKROBONJA, „Hasta la vista”, 6.

55 Videti: Теодор АНЂЕАИЋ, „За балканизацију Европе”, НИН, 13. 2. 1983., 32.; 3. МАРКУШ, Зенитизам, 38.-42.; Borislav MIHAJLOVIĆ, Autobiografija o drugima, II, Novi Sad 2003., 55.; Irina SUBOTIĆ, „Susret s Irinom Aleksander", u: Irina ALEKSANDER, Svi životi jedne ljubavi, Zagreb 2003., 228.

56 Вилијам АБРАМЧИК, [Велимир Абрамовић], „К ьуч за европеизацију Балкана”, Книжевне новине, 34/1983., br. 664, 35.-36. Ovde se aludira na Oskara Daviča, Marka Ristića i Koču Popovića.

57 3. МАРКУШ, Зенитизам, 38.
} 


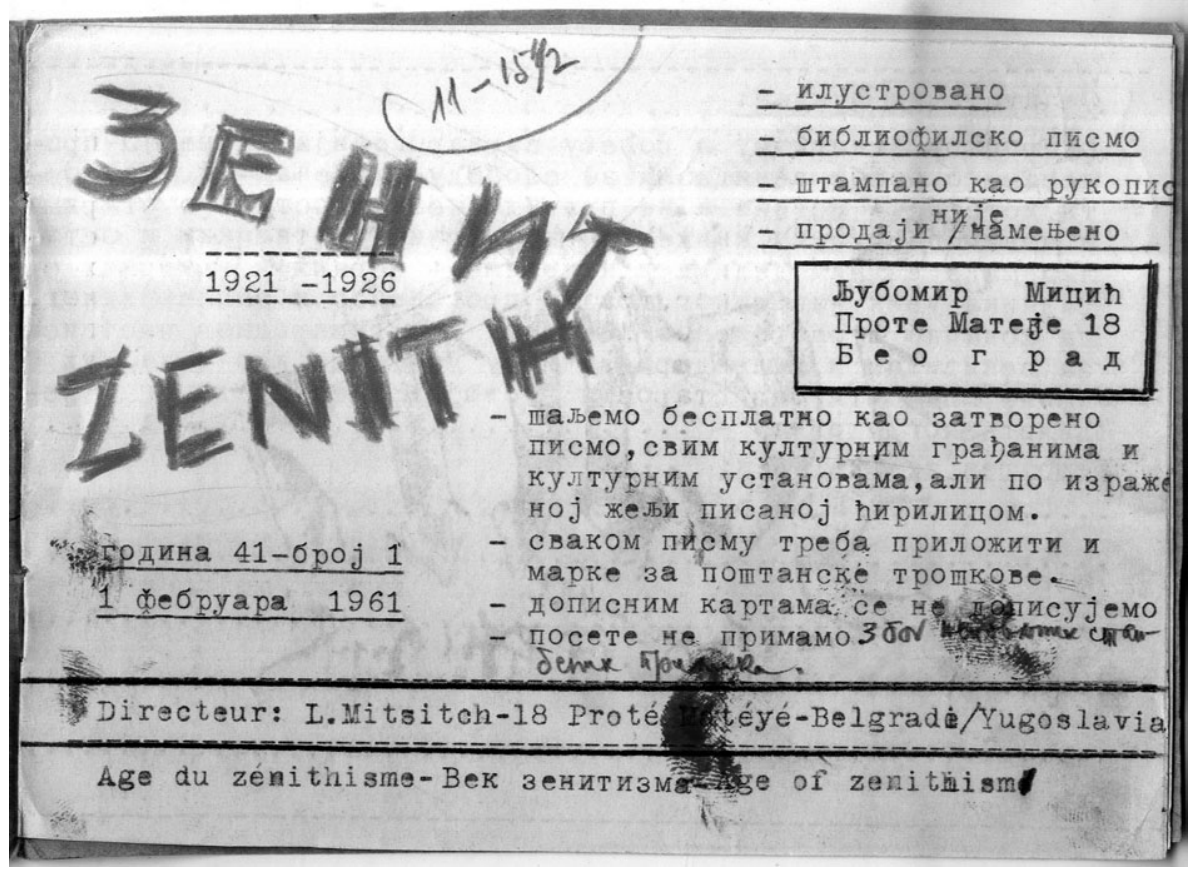

Slika 3. Micićevo „bibliofilsko pismo” - rijedak primjer samizdata u Jugoslaviji i Micićev pokušaj obnove Zenita. Beograd, 1. veljače 1961.

opština Srpske pravoslavne crkve u Trstu..$^{58}$ Tokom 1953. godine protiv Micića su njegovi susedi podneli nekoliko tužbi, zbog kojih je bio u istražnom zatvoru. Na Micićevu žalbu da mu je stalno ponižavanje, uznemiravanje i klevetanje od strane sustanara oštetilo zdravlje i nerve, sudija ga je 1954. godine poslao u duševnu bolnicu, na posmatranje. ${ }^{59}$ Sledeći put Micić je izveden na sud 1960, jer je u privatnoj pošti i nekim svojim izjavama vređao visoke funkcionere i širio „nacionalnu i versku netrpeljivost, mržnju i razdor”. ${ }^{60}$ Suđenje je obustavljeno jer je istražni sudija odustao od daljeg gonjenja. Sve što je Micić radio posle rata ostalo je u skicama ili je to sam umnožavao i kao samizdat slao poštom, mahom adresatima u inostranstvu. ${ }^{61}$

Sačuvana je božićna čestitka sa pesmom, napisana na lošem engleskom jeziku, koju je Micić 11. XI 1958. adresirao na Frederika Pregera (Frederic Praeger), poznatog američkog izdavača antikomunističke literature. ${ }^{62}$ Adresatu je otvoreno sugerisao da sadržaj kopira i šalje dalje. Čestitka je, u stvari, bila upućena široj javnosti, „to the Churchill's english-speaking people”, koji su, po Micićevom mišljneju, „supporters of red star supremacy”. Pesma se završava rečima: „By red pigs blasphemed the famous Nobel Prize”, što upućuje na zbivanja

\footnotetext{
58 Z. MARKUŠ, „Razgovori sa Lj. Micićem, 1”, Odjek, 24/1971., br. 20, 20.; Ирина СУБОТИЋ, „Сећања на сусрете са Бубомиром Мицићем”, Книжевност, 37/1981., br. 7-8, 1486.; B. SKROBONJA, „Hasta la vista”, 2.-24.

59 Luka DOTLIĆ, „Sporovi Ljubomira Micića”, Polja, 17/1971., br. 152, 4.-5.

60 B. SKROBONJA, „Hasta la vista”, 7.

61 Drugi primeri samizdata u Jugoslaviji nisu poznati. Jedan broj Micićevih malotiražnih „bibliofilskih pisama” (tj. samizdata) čuva se u njegovom fondu u NBS, dok su neki faksimili objavljeni u: 3. МАРКУШ, Зенитизам, I.-XX.

62 Preger je tokom rata bio američki obaveštajni oficir, a i kasnije je ostao tesno povezan sa CIA. U Njujorku je 1950. osnovao izdavačku kuću Praeger Publishers, koja je, pored ostalog, objavila dela A. Solženjicina i M. Đilasa. Videti: Mira BOGDANOVIĆ, „Jugoslavenski disidenti i hladni rat”, Sociologija, 6/2009., br. 2, 123.
} 
povodom dodeljivanja Nobelove nagrade Pasternaku. ${ }^{63}$ Ukoliko bi se primenili kriterijumi koji važe za disidente u SSSR-u, onda bi se za Micića moglo reći, pre nego za neke druge osobe (npr. za Milovana Đilasa), da je bio disident: bio je principijelni i dosledni protivnik komunističkog režima, nije težio dolasku na vlast, delovao je putem samizdata i prepiske, bio je zbog toga maltretiran, suđen, zatvaran i slat u duševnu bolnicu na posmaranje. ${ }^{64}$ Zbog svega navedenog, nekadašnji zenitista je verovao da je pod stalnom prismotrom, ali „(n)i jednog trenutka, međutim, Micić nije smatrao da sve to potiče od službi unutrašnjih poslova,već iz intelektualnih krugova..." ${ }^{65}$ Zaista, on u tim krugovima nije bio zaboravljen. Njegovoj ličnosti je 1969. godine posvećen razorni i zastrašujući esej u kome se kaže:

Barbarogenije je sinonim tog varvarskog straha od tuđinskog mora, od kulture koja je uvek šansa da to more, kao neka biblijska stihija, prodre u naše selo, da nas razveje i otuđi od nas samih, od našeg duha, sloga i sroka, od naših mrtvih, od naše tradicije. (...) On je tu, Barbarogenije, najmračniji genije srpske kulture; on je tu... ${ }^{66}$

Micićeva odbačenost i usamljenost postale su naročito teške posle 1961. godine, kada je umrla Anuška, poslednji i najjači oslonac koji je imao. Za sebe je u to vreme govorio da je „leš koji hoda”. ${ }^{67}$ Kada je 12. juna 1971. godine, tačno na pedesetogodišnjicu Manifesta zenitizma, nađen u besvesnom stanju u svom stanu, opravdano se smatralo da je u pitanju samoubistvo. ${ }^{68}$ Micić svoj život nije delio od svoje umetnosti, a u njegovim postupcima i stvaralaštvu uvek je bilo i simbolike i mistike. Umro je par dana kasnije. ${ }^{69}$

Mikcu je, takođe, od strane komunističke vlasti bilo namenjeno da potpuno nestane iz kulture Jugoslavije. ${ }^{70}$ Ipak, on je kao emigrant imao daleko više mogućnosti za intelektualni rad nego da je ostao u Jugoslaviji, tako da je njegova posleratna bibliografija daleko obimnija od predratne. ${ }^{71}$ Umro je 16. marta 1972, na brodu kraj obale Južne Afrike. U Jugoslovenskom književnom leksikonu ni jedan od njih dvojice nije pomenut poimence. ${ }^{72}$ Postoji samo odrednica „Zenitizam”, u kojoj se pominje Micićevo, ne i Mikčevo ime. Kada je Mikac u pitanju, to objašnjava činjenica da je bio aktivan u krugovima oko ustaškog časopisa Obrana, a objavljivao je i u drugim emigrantskim publikacijama. ${ }^{73}$

63 NBS, LjMR/I. Božićna čestitka Micića Pregeru, Beograd 11. 11. 1958.

64 Uporediti sa: Goran MILORADOVIĆ, „Ljudi na strateškim mestima: uzroci, posledice i smisao sukoba Josipa Broza Tita i Milovana Đilasa na Trećem (vanrednom) plenumu CK SKJ 1954. godine”, Tito - viđenja i tumačenja, (zbornik radova), Beograd 2011., 202.-210., 229.

65 3. МАРКУШ, Зенитизам, 39.

66 Radomir KONSTANTINOVIĆ, „Ko je barbarogenije”, Treći program, 1/1969., proleće, 20.-21. (kurziv R. K.). Stiče se utisak da autor eseja ne govori o „barbarogeniju” samo kao o simbolu, nego da je svestan i Micićevog fizičkog prisustva. Izolovan, proskribovan i kontrolisan, Micić nije mogao da odgovori.

67 O ljubavi, privrženosti i poštovanju koje je Micić negovao prema supruzi govori podatak da je tokom poslednje decenije svog života svakog dana odlazio na njen grob, uređivao ga i nad njim čitao poeziju. Videti: B. SKROBONJA, „Hasta la vista”, 7.

68 Micić je to bio najavio svom poznaniku Z. Markušu. Videti: 3. МАРКУШ, Зенитизам, 41.

69 Postoji legenda, koja je, izgleda, potekla od J. Seissela, da je Mikac bio na Micićevoj sahrani. Međutim, teško je poverovati u to. Mikac je pripadao ekstremnoj političkoj emigraciji, pa bi pri pokušaju ulaska u zemlju bio uhapšen. Na sahrani je od starog zenitističkog društva bio V. Skerl, koji je možda pogrešno identifikovan kao Mikac. Videti: Vera HORVAT-PINTARIĆ, Josip Seissel, Zagreb 1978. (nap. 3.); В. SKROBONJA, „Hasta la vista”, 20; Б. ВРГА, „Зенитистичке вечерње”, 391. (nap. 10.).

70 Branimir DONAT, „Zaboravljeni i nepoznati Marijan Mikac”, Kolo Matice hrvatske, 3/1993., br. 9-10, 711.-737.

71 Videti: Zlata DEROSSI, „Marijan Mikac, (Senj 29. 1. 1903. - Atlantik kod Cape Towna 16. 3. 1972.)”, Senjski zbornik, 24/1997., br. 24, 221.-225.

72 Jugoslovenski književni leksikon, Novi Sad 1970., 15., 586.

73 Videti: Z. DEROSSI, „Marijan Mikac”, 169.-226. Većina onoga što je Mikac objavio u emigraciji podrivala je tadašnji ustavni poredak Jugoslavije. 
Micić je odbacivan koliko zbog svog, u to vreme već nepomirljivog nacionalizma, toliko i zbog lične netrpeljivosti nekih bivših pripadnika nadrealističkih krugova, koji su u novim okolnostima stekli političku i društvenu moć. ${ }^{74} \mathrm{O}$ zenitizmu se znalo i ponešto pisalo isključivo u stručnim krugovima i, uglavnom, uzgred. ${ }^{75}$ Šira javnost je o tom umetničkom pokretu kao o centralnoj temi mogla nešto više da sazna tek početkom 1983. godine, povodom izložbe Zenit i avangarda dvadesetih godina, koja je održana u Beogradu i Zagrebu. ${ }^{76}$ Međutim, ta izložba je, pored ostalih reakcija, izazvala i oštru polemiku ideološkog i političkog karaktera. ${ }^{77}$

\section{Ideološka evolucija Ljubomira Micića i Marijana Mikca}

Očigledna i drastična ideološka i politička evolucija Micića i Mikca i njihovo nezadrživo kretanje sa anarhističke i internacionalističke levice ka nacionalističkoj, a potom i šovinističkoj desnici, koje je posle propasti Zenita sve brže i jače zahvatalo obojicu, može se pratiti kroz njihovo stvaralaštvo, kroz štampu, prepisku i drugu građu. Bez pretenzija da se iscrpu svi mogući aspekti problema, ovde je izdvojeno nekoliko pojmova indikativnih za promenu njihovih pogleda na svet. Iako je Mikac u Zenitu znatno manje objavljivao nego Micić, činjenica da je ostao jedan od najupornijih i najdoslednijih zenitista govori o tome da u vreme izlaženja Zenita nije imao drugačija shvatanja od vođe pokreta. Da jeste, mogao se distancirati i od časopisa i od urednika, kao što su mnogi drugi saradnici i učinili.

Revolucija. Zenitizam je bio jedan od umetničkih pokreta koji su se pojavili kao reakcija na Prvi svetski rat i koji je svoj društveni zamah i ambicije, pored ostalog, crpao i iz simboličnog značenja Oktobarske revolucije. Zbog toga je doživljavan, a i sam se deklarisao, kao „levičarska struja” tadašnje umetničke scene. ${ }^{78}$ Već u prvom broju Zenita Micić je objavio članak Proletkult Anatolija Lunačarskog, narodnog komesara za prosvetu Sovjetske Rusije. ${ }^{79}$ Tada Ljubomir Micić umetnost definiše kao „večnu revoluciju”, ${ }^{80}$ potom objavljuje „novelu” Revolucija u gradu belome, ${ }^{81}$ a ponekad se pak čini da reč „revolucija” u svojim

74 Za nadrealiste je Micić pisao da su „beogradski književni snobovi, kojima je Frojdova psihoanaliza pomela i ono malo mozga što ga imaju”. ऽ[убомир], М[ИЦИТ], „Песник у кудници”, Зенит, 5/1925., br. 36, [17.]

75 Videti: Miodrag PROTIĆ, Tré́a decenija. Konstruktivno slikarstvo, Beograd 1967.; Миолраг ПРОТИЋ, Сриско сликарство XX века, БеограА 1970.; V. HORVAT-PINTARIĆ, Josip Seissel. O zenitizmu kao osnovnoj temi Zoran Markuš je tokom sedamdesetih godina objavio nekoliko kraćih članaka u časopisu Delo.

76 Irina SUBOTIĆ, Zenit i avangarda 20ih godina (katalog izložbe), Beograd 1983.; Aleksandar FLAKER, Ruska avangarda, Zagreb 1984., 439.-458.

77 Videti: Вимијам АБРАМЧИК, „Кьуч за европеизацију Балкана”, 35.-36.; Т. АНЂЕ АИЋ, „За балканизацију Европе”, 32.-33.; РаАивој ЦВЕТИЋАНИН, „Утаја 'србијанства', случајно или не”, Недељьа борба, 19-20. II. 1983., 11.; Р[адован] ПОПОВИТ, „Мицић и његов зенитизам”, Политика, br. 24924, 25. 2. 1983., 10.; Zoran MARKUŠ, „Što je želio Micić”, Danas (Zagreb), br. 55, 8. 3. 1983., 40.; Momčilo ĐORGOVIĆ, „Barbarogenij još jednom”, isto, 63.-64.; Стеван СТАНИЋ, „Између “србијанства' и космополитизма” (интервју са БогАаном Богдановићем), НИН, br. 1682, 27. 3. 1983., 27.-30.; Ирина СУБОТИЋ, „Зенит и авангарда”, Књижевне новине, br. 669., 28. 4. 1983., 6. Ovim se lista polemičkih i drugih tekstova objavljenih povodom izložbe Zenit i avangarda dvadesetih godina ne iscrpljuje.

78 Ь. МИЦИЋ, „Аегенда о 'мртвом покрету”, 3.-4.

79 A[natolij] LUNAČARSKI, „Proletkult”, Zenit, 1/1921., br. 1, 11.-12.; isto, 1/1921., br. 2, 13.-14.

80 Lj. MICIĆ, „Čovek i umetnost”, 1.-2.

81 Lj. MICIĆ, „Revolucija u gradu belome”, 2.-7. 
tekstovima koristi samo radi provociranja. ${ }^{82} \mathrm{U}$ Micićevoj zbirci poezije Antievropa u gotovo svakoj pesmi pominje se reč „revolucija”. ${ }^{83}$ Zenitistička „revolucija” bila je poetski izraz ogorčenosti proteklim ratom kao ishodištem evropske istorije, ali i zahtev za promenom generalnog diskursa, što je bilo jasno izrečeno:

Ovde je delimično iskazan put i pesničke revolucije, koju su zenitisti otpočeli početkom ovoga decenija. Ona se progresivno sve više nameće kao postulat i kategorički imperativ, neposredno kao druga karika socialnih revolucija, koje su potresle i delomično ugrozile temelje kapitalističkog društva. ${ }^{84}$

Tokom dvadesetih godina postojalo je saglasje Micića i Mikca u vezi sa „revolucijom”. Mikac je u jednoj svojoj pesmi pretio predstojećim revolucionarnim promenama: „Gde je još ono vreme / Kada će žene kapitalista prati rublje / A pralje u kafani zobati cvebe / Suviše smo daleko da se nazovemo drugom”. ${ }^{5}$ Poljanski je provokativno ponavljao „Revo / Revo / Revo / U tebe su divne oči Lucija”, ${ }^{86}$ a Micić se nadovezivao: „Urliču janičari revolucije / Za novo čovečanstvo sve u kovitlac" ${ }^{87} \mathrm{Za}$ teme u vezi ruske revolucije uvek se nalazilo mesto u Zenitu. ${ }^{88} \mathrm{U}$ svom tekstu Zenitistička nova umetnost Marijan Mikac proklamuje: „Zenitizam je nov pokret u umetnosti. Kao takav zenitizam je revolucionaran." ${ }^{99}$ Međutim, vremenom su se stvari promenile, pa je Mikac tridesetih godina u Ruskoj revoluciji počeo da vidi ostvarenje ,jevrejskih interesa”. Zato on u svom romanu Doživljaji Morica Śvarca sarkastično komentariše da američka „dobrotvorna društva za potpomaganje siromašnih Židova (...) brinu najviše za Židove iz inozemstva, da su ona - milijunima dolara - pomagala Židove, na primjer, za vrijeme ruske revolucije.” ${ }^{90}$ Pobeda stvarne (a ne „pesničke”) revolucije u Jugoslaviji obojicu je uklonila sa kulturne scene. Mikac je napustio Jugoslaviju, a Micić se našao u situaciji da ga ministar Vladislav Ribnikar, nekadašnji urednik i vlasnik Politike, sa kojom je zbog svoje „revolucionarnosti” svojevremeno bio u sukobu, progoni u ime - revolucionarnih načela! ${ }^{\text {"1 }}$

Anarbizam. U prvom tekstu prvog broja Zenita, u Micićevom tekstu Čovek i Umetnost, može se naći misao: „DUH ili polubog Anarh, hoće u haosu da bude vladar - 'vsevolod', da bude bog. On žudi - iz haosa stvoriti delo." ${ }^{2}$ Već prilikom objavljivanja Zenitističkog manifesta 12. juna 1921. ponovo je naglašeno: „Vodi nas mistični polubog ANARH”. ${ }^{93}$ Micić je kasnije to i obrazložio:

Zenitizam je duh slobodan, duh koji je neovisan u traženju: svoje forme - svoga stila - svoga 'Ja' - svoje individualnosti. (...) Zenitizam u težnji za oslobođenjem čoveka, u težnji za

\footnotetext{
82 Ljubomir MICIĆ, „Reči u prostoru”, Zenit, 2/1922., br. 14, 25.; Ljubomir MICIĆ, „Sud porote”, Zenit, 3/1923., br. 21, [3.-4.]

83 Бубомир МИЦИЋ, Антиевропа, Београд 1926. Pesme su prethodno bile objavljene u Zenitu.

84 Ljubomir MICIĆ, „Radio, film i zenitistička okomica duha”, Zenit, 3/1923., br. 23, [2.-5.]

85 Marijan MIKAC, „Kontracveba - gospodična”, Zenit, 3/1923., br. 23, [6.]

86 Бранко Ве ПОААНСКИ, „У тебе су Аивне очи Ауција”, Зенит, 6/1926., br. 39, [21.]

87 Һубомир МИЦИЋ, „Бим бам бом”, Зенит, 6/1926., br. 41, [5.]

88 Максим ГОРКИ, „Поводом револуције”, Зенит, 4/1924., br. 34, [13.-14.]; исто, 4/1924., br. 35, [11.-12.]

89 Маријан МИКАЦ, „Зенитистичка нова уметност”, Авангарда. Свеске за теорију и историју книжевно/уметничког експеримента, 2/1998. -2000., br. 2-4, БеограА 2001., 162.

90 Marijan MIKAC, Doživljaji Morica Švarca u Hitlerovoj Njemačkoj, Zagreb 1937., 48.-49.

91 3. МАРКУШ, Зенитизам, 37.-38; „Kako je 'Zenit' obustavio 'Politiku’”, Зенит, 6/1926., br. 43, [23.-24.]

92 Lj. MICIĆ, „Čovek i Umetnost”, 1. Naglašena reč u originalu.

93 Lj. MICIĆ - I. GOLL - B. TOKIN, „Manifest zenitizma”, 119. Naglašena reč u originalu.
} 
njegovom individualizacijom, ujedno je anarhija, čije je religija: stvoriti nove forme i odnosne kao duhovne temelje budućoj balkansko-čovečnoj umetnosti i svojim pozitivnim delom uništiti nečovečnu i neduhovnu prošlost sviju..$^{4}$

Na drugom mestu Micić kaže:

Novi pesnici fanatici su novog stvaranja. Duhovni buntovnici i anarhisti. Njihova anarhija zavet je duha za oslobođenjem čoveka od patosa, materije egoizma i crnog zločina. (...) Pesnikova anarhija i plamen je: REČ ${ }^{95}$

Kasnije, tokom 1926, u Micićevoj prozi pojavljuje se lik po imenu Anarh Glad, ${ }^{96}$ njegov alter ego, kao što je to na drugim mestima Barbarogenije. Ime junaka Anarha ne treba posebno objašnjavati, a prezime Glad je možda odraz činjenice da je Micić tokom 1924. godine bio prisiljen da radi kao trgovački pomoćnik, da bi se sa suprugom prehranio. ${ }^{97}$ To poniženje, kojim je ne samo degradiran nego mu je oduzeta i sloboda, dodatno ga je revoltiralo. Kasnije, 1930. godine, francuski pisac i urednik Marijis Boason (Marius Boisson) za Micića je napisao da je pesnik „pod plaštom ciničkog filozofa i osvetničkog anarhiste”. Micić se svakako slagao sa tom definicijom, jer ju je štampao 1940. godine, ponovo se predstavljajući domaćoj publici. ${ }^{98}$

Marksizam, boljševizam, komunizam. Tokom 1920-ih godina Micić i Mikac su, shodno izrazito levičarskoj orijentaciji časopisa, bili protivnici kapitalizma i politike koju on produkuje. Međutim, sadržaja koji bi se nedvosmisleno mogli nazvati marksističkim u Zenitu je bilo relativno malo. Jedan od primera je Micićev tekst koji počinje rečenicom: „Svetska buržoazija nikako neće da prizna, da je jedino Lenjinovo gledište na svetski rat bilo tačno i da ostaje tačno." ${ }^{99}$ Ceo taj tekst je prožet Lenjinovim shvatanjima o imperijalizmu i kolonijalizmu, tako da je Micić nesumnjivo nešto od toga i čitao. ${ }^{100}$ Pored toga, bilo je i drugog prosovjetskog istupanja, što pojačava utisak marskističke orijentacije Zenita. Tokom pet godina izlaženja, u časopisu su objavljena, pored ostalog, brojna dela sovjetskih umetnika: poezija Majakovskog, Jesenjina, Bloka, Asejeva, Lisickog, Maljeviča, Petnjikova, Rodčenka, Tatlina i Pasternaka, dvobroj Zenita 17-18 bio je u celini posvećen „ruskoj novoj umetnosti”, ${ }^{101}$ a časopis je obeležio i neke sovjetske jubileje. ${ }^{102}$ Micić je 1926. godine tvrdio da su se „najjasnije ispoljila dva fronta: levi front ZENITA i ZENITIZMA - desni front: sve drugo". ${ }^{103}$ Vođa zenitizma se ponekad sastajao sa poznatim ličnostima koje su važile za marksiste ili komuniste - u Parizu sa Majakovskim, a u Beogradu sa Anri Barbisom, što je policija opazila (i sovjetska i jugoslovenska). ${ }^{104}$ Postoje dokazi da se Micić povremeno

\footnotetext{
94 Ljubomir MICIĆ, „Duh Zenitizma”, Zenit, 1/1921., br. 7, 4. Naglašene reči u originalu.

95 Ljubomir MICIĆ, „Delo zenitizma”, Zenit, 1/1921., br. 8, 2.-3. Naglašena reč u originalu.

96 Бубомир МИЦИЋ, „Ае Гиди бекјар будама”, Зенит, 6/1926., br. 40, [4.-10.]

97 Бубомир МИЦИЋ, „Хвала ти Србијо мепа”, Зенит, 5/1925., br. 36, [4.]; Фубомир, МИЦИт, „За слободу мисли, за слободу стварања”, Зенит, 6/1926., br. 41, 10.

98 Cрбијанство, 2. Boasonovo mišljenje je navedeno iz časopisa Comoedia, [Paris], 1930.

99 Бубомир МИЦИТ, „Мароко и опет за спас цивимизације. Империјализам је библија Европе и Европејаца”. Зенит, 5/1925., br. 37, [3.-6.]

100 Uporediti: В. И. АЕНИН, Полное собрание сочинений, Том 28, (Тетради по империализму), Москва 1962.

101 Zenit, 2/1922., br. 17.-18.

102 Tekst povodom Lenjinovog pedesetog rođendana: Аав ТРОЦКИ, „Аењин”, Зенит, 4/1924., br. 26-33, [25.-27.]

103 УРЕАНИШТВО ЗЕНИТА, „Фимм јеАног књижевног покрета”, [37.]

104 Бубомир МИЦИЋ, „Мој сусрет са Анри Барбисом”, Зенит, 6/1926., br. 41, 17.-21.
} 
družio i sa braćom Bihalji, Pavlom i Otom, koji su obojica bili komunisti. ${ }^{105}$ Osim toga, zalažući se za „novog čoveka” zenitisti u osnovi slede marksistički zahtev za otpočinjanjem „istinske istorije”, koja će početi revolucijom i stvoriti „novog”, („zenitističkog”, „varvarskog"), ali svakako - boljeg čoveka. ${ }^{106} \mathrm{Od}$ tog zahteva Micić nije nikada odustao, iako nije bio član Komunističke partije. ${ }^{107} \mathrm{Na}$ kraju je Zenit zabranjen zbog propagiranja marksizma. ${ }^{108}$ Međutim, trisesetih godina, dok Micić u emigraciji istrajava na neprijateljskom stavu prema establišmentu Jugoslavije i vrednostima koje on zastupa, Mikac odustaje od te borbe i uklapa se u postojeći poredak stvari, postavši i sam preduzetnik. ${ }^{109} \mathrm{Za}$ Micića su u to vreme neposredni neprijatelji bili vladajući krugovi u Jugoslaviji, a posebno je kritičan prema lideru Narodne seljačke stranke Dragoljubu Jovanoviću, ministru unutrašnjih poslova Antonu Korošecu i kralju Aleksandru. ${ }^{110}$ Kada je reč o opštem planu, za Micića je kapitalistička „bratoubilačka i čovekoubilačka civilizacija” i dalje najveći neprijatelj. ${ }^{111}$ On u svom romanu optužuje „Evropu” da „žudi za zlatom”, ${ }^{112}$ a kao predstavnika materijalističkih shvatanja, berze i krupnog kapitala u roman uvodi lik „gazde Hipokrita”, lokalnog izdanka evropske buržoazije. ${ }^{113}$ Krajem tridesetih godina Micić odbacuje i komunizam, tvrdeći da je on „u službi fanatika i vucibatina”." ${ }^{114}$ Ta promena stava imaće, kasnije, dalekosežne posledice po njega...

Internacionalizam. Od prvog do poslednjeg broja u zaglavlju Zenita je stajalo da je u pitanju „internacionalni” („međunarodni”) časopis, tj. „revue internationale”, što se vidi i iz sastava njegovih saradnika. ${ }^{115}$ To nije ostalo samo težnja, jer je zenitizam bio primećen i prihvaćen i u drugim zemljama: Rusiji, Belgiji, Holandiji, Francuskoj, Nemačkoj, Čehoslovačkoj, Mađarskoj, Italiji, i drugde... ${ }^{116} \mathrm{U}$ svom manifestu objavljenom u Zenitu Ivan Gol proklamuje: „ČOVEK! Mi nismo ni Francuzi, ni Srbi, ni Nemci, ni Crnci, ni Luksemburžani! Mi smo Evropljani, Amerikanci, Afrikanci, Azijci, Australijanci!"117 Ali, nije se to odnosilo samo na raznovrsna porekla i jezike onih koji su u časopisu objavljivali, već i na idejnu orijentaciju zenitizma. Po definiciji, internacionalizam označava pokret za međunarodnu solidarnost i ravnopravnost, kao i borbu protiv rasnih, klasnih i nacionalnih predrasuda, protiv šovinizma, imperijalizma i militarizma. ${ }^{118}$ Takvim temama časopis Zenit obiluje, a naročito Micićevi tekstovi. U programskom tekstu prvog broja Zenita Micić je

105 Videti: В. ГОАУБОВИЋ - И. СУБОТИЋ, Зенит, 198.-199., 201.-203.

106 Lj. MICIĆ, „Čovek i Umetnost”, 1.-2.; L. MICIĆ - I. GOLL - B. TOKIN, „Manifest zenitizma”, 117.-119.; ьубомир МИЦИЋ, Барбарогеније дечивилизатор, БеограА 1993., 132., 158.

107 To je tvrdio V. Skerl. Prema: B. SKROBONJA, „Hasta la vista”, 21.

108 Povod je bio članak potpisan pseudonimom: М. РАСИНОВ, „Зенитизам кроз призму марксизма”, 12.-15.

109 NBS, LjMR/II/2. Pismo Mikca Miciću, Berlin, 9. 11. 1931; Pismo Mikca Miciću, Berlin, 19. 11. 1931; Pismo Mikca Miciću, Zagreb 27. 5. 1938.

110 ๖. МИЦИЋ, Барбарогеније, 42.-45., 57.-64., 81., 85., 88. Prvu dvojicu Micić ne pominje imenom, ali pominje profesije, funkcije i postupke preko kojih se mogu prepoznati.

111 Isto, 13. i 16.

112 Isto, 13.

113 Isto, 13.-16. Reč „hipokrit” je u romanu lično ime, a znači: licemer, dvoličnjak.

114 Isto, 77.

115 В. ГОАУБОВИЋ - И. СУБОТИЋ, Зенит, 18.-19. V. Golubović, govoreći o zenitizmu i Zenitu, koristi izraze „radikalni internacionalizam” i ,radikalni međunarodni forum”.

116 3. МАРКУШ, Зенитизам, 62.-96.

117 Ivan GOLL, „Zenitistisches Manifest”, Zenit, 1/1921., br. 5, 1.-2.

118 Миман ВУЈАК ИИА, Аексикон страних речи и израза, БеограА 1991.; Иван КААЈН, Миман ШИПКА, Велики речник страних речи и израза, Нови СаА 2006. 
proklamovao za šta se zalaže: „Naša borba biće borba protiv zločina - za Čoveka. Proleteri sviju zemalja, ujedinite se - protiv ubijanja!" 119 Reč „Čovek”, sa velikom početnim slovom, koja se (tako napisana) često pojavljivala u Micićevim tekstovima, ukazuje na to da je u pitanju najšire moguće značenje te reči, da je u pitanju „Čovek” bez rasnih, nacionalnih ili verskih predznaka. U udarnom tekstu drugog broja Zenita Boško Tokin je, odgovarajući na kritike, pisao: „Verovatno da su slični pokreti na strani, jer je nova umetnost internacionalna, i to je ono što mnogi od napadača zaboravljaju, uticali mestimice na nas, pošto je to isti duh." ${ }^{\prime 20}$ Osim toga, Zenit je prvi u Jugoslaviji, u dva svoja broja, objavio nacrt Tatlinovog spomenika Trećoj internacionali. ${ }^{121} \mathrm{Na}$ Micića je to delo sigurno ostavilo snažan utisak, jer se i kasnije, u svom teorijskom i praktičnom radu, pozivao na njega. ${ }^{122}$ Svakako su se u to vreme i svi saradnici Zenita, uključujući i Mikca, slagali sa takvom orijentacijom lista koji je Micić uređivao.

Nacionalizam. Političke i međunacionalne tenzije u Kraljevini SHS bile su snažne od samog njenog nastanka. Početkom dvadesetih godina Mikac i Micić su bili saglasni u suprotstavljanju nacionalizmu, ali su vremenom podlegli uticajima svog okruženja. Štampa je zabeležila debate koje je u Petrinji vodio Marijan Mikac, gde su se koplja lomila mahom oko onoga što je politizovanoj, netolerantnoj i ostrašćenoj sredini moglo zaličiti na ,jugoslovenstvo". Mikac je tokom 1920/21. godine svojim istupanjima navukao gnev i omalovažavanje krugova bliskih Hrvatskoj republikanskoj seljačkoj stranci (HRSS), koji su smatrali da on promoviše međunacionalno zbližavanje. ${ }^{123}$ Mikac se 1920. godine oglasio u Jedinstvu, listu Jugoslovenske demokratske stranke, osuđujući „separatistički program hrvatskih zajedničara” i zalažući se za „narodno i državno jedinstvo”. ${ }^{124}$ Prilikom osnivanja petrinjske podružnice Društva hrvatskih žena iznošeni su „frankovački i harangerski” stavovi, a kada je Mikac rekao „da bi se ipak moglo raditi u smislu prijateljstva prema Srpkinjama i Slovenkama, prolomilo se urnebesno 'Nećemo!'”125 Svoj nastup Mikac je obrazložio rečima kako je „vjerovao da će skupština odisati idejom zbližavanja, a ne dijeljenja, jer uostalom ženski je pokret internacionalan”, dodavši da je on reč tražio uvidevši da je to „politički zbor, duboko šovinističkog karaktera”, i zaključivši: „Zar sam mogao znati da će sve te 'vrle' $\mathrm{Hr}$ vatice natjerati u bjesnilo i sam poziv na složan rad sa srpskim ženama?" ${ }^{26}$ Zbog tadašnjih svojih stavova Mikac je bio uziman za negativan primer ,jugoslavenskog odgoja”. ${ }^{127}$ Usled takvih okolnosti on je, uprkos entuzijazmu i uloženoj energiji, ostao usamljen i odbačen od svog neposrednog okruženja, prisiljen da se bori za golu egzistenciju. ${ }^{128} \mathrm{U}$ knjizi Stotinu vam bogova Micić je 1922. napisao da se za status „slobodnog zenitističkog građanina”, pored ostalog, traži i „,svedodžba o antipolitičkoj vrlini koja uvetuje čistoću ličnosti našega

\footnotetext{
119 Lj. MICIĆ, „Čovek i Umetnost”, 1.-2.

120 Boško TOKIN, „Mladi reakcionari i novi duh”, Zenit, 1/1921., br. 2, 1.

121 Videti: Zenit, 2/1922., br. 11, 2.; Zenit, 2/1922., br. 17-18, 52.

${ }^{122}$ Ljubomir MICIĆ, „Kategorički imperativ zenitističke pesničke škole”, Zenit, 2/1922., br. 13, 18.; Фубомир МИЦИЋ, „Стотину вам богова”, Авангарда. Свеске за теорију и историју книжевно/уметничког експеримента 2/1998.-2000., br. 2-4, БеограА 2001., 138.

123 Videti: Б. ВРГА, „Зенитистичке вечерње”, 387.-390.

124 Isto, 387, nap. br. 3. Mikčev tekst u Jedinstvu od 12. 10. 1920., objavljen je pod naslovom „Sačuvaj nas bože takvih patriota”.

125 Isto, 388, nap. br. 3. Citat iz lista Jedinstvo, 2. 8. 1921.

126 Isto, 389, nap. br. 3. Citat iz lista Jedinstvo, 23. 8. 1921

127 Isto, 389, nap. br. 3. Citat iz nedeljnika HRSS-a u Petrinji Hrvatska banovina, od 27. 8. 1921.

${ }^{128}$ Isto, 384-391; NBS, LjMR/II/2. Mikčevo pismo Miciću, Petrinja, 20. 8. 1923.; Mikčevo pismo Miciću, Sarajevo, 25. X. 1923.; Mikčevo pismo Miciću, Sarajevo, 9. 12. 1923.; itd...
} 
tipa - njezino uzvišenje nad uskogrudni malonarodni nacionalizam. (Politika nacionalizma: inferiorna žaba gatalinka!)”. ${ }^{129}$ Nacionalna šarolikost autora koji su objavljivali u prvim brojevima Zenita potvrđuje da njegov urednik tada nije bio opterećen nacionalnom distanciranošću. Prvi veći Micićev sukob desio se kada je u Zenitu štampan nipodaštavajući i antikerikalno intonirani prikaz dvobroja zagrebačkog časopisa Kritika posvećenog Danteu. ${ }^{130}$ U nepotpisanom tekstu u Zenitu se, pored ostalog, kaže:

Gospodo latinska! Imate li vi jačeg i dubljeg opravdanja zato što slavite u svojoj slabosti boljeg pesnika od Vas ili je to samo majmunisanje i puzanje za Latinima i Evropom? Pužite! Samo pužite! $!^{131}$

Uredništvo Kritike mu je odgovorilo tekstom punim prezira i omalovažavanja u rubrici Tajget, pod kojom „(...) izlažu sve one literarne nezrelosti, blesavosti i djetinjarije koje bi naše društvo moralo strpati u moderni Tajget - u ludnicu. (...) polemika je preveć ozbiljno sredstvo za borbu protiv literarnih manijaka i duševnih slijepaca." ${ }^{132}$ Međutim, taj sukob, koji otkriva suprotstavljenost književnika okupljenih oko određenih časopisa i ličnu netrpeljivost pojedinaca, još uvek nije bio dokaz nacionalne omraze. ${ }^{133} \mathrm{Ali}$, i do toga je, uskoro, došlo. Usijana politička scena Kraljevine SHS delovala je i na Micića, tako da je, isprovociran omalovažavajućim izjavama vođe HRSS-a Stjepana Radića, 1923. napisao i u Zenitu dva puta objavio tekst „Papiga i monopol 'hrvatska kultura”. ${ }^{134}$ Prema mišljenju Radomira Konstantinovića, Miciću se „Evropa (...) ukazivala u sećanju, kao Austro-Ugarska, a u živoj njegovoj svakodnevici, posle prvog rata, kao Hrvatska, čiji je duh izjednačavao sa duhom Austro-Ugarske." 135 To može biti tačno kada je reč o onom delu političkog i kulturnog miljea sa kojim se Micić sukobio, ali treba imati u vidu da to nije bila celokupna javna i umetnička scena - bilo je i onih Hrvata sa kojima je Micić i dalje sarađivao. Vera HorvatPintarić je svojevremeno konstatovala: „Suradnja Lj. Micića s hrvatskim slikarima i piscima bila je vrlo bliska (...)", a potom je nabrojala Vilka Gecana, Marijana Mikca, Josipa Seissela, Anku Krizmanić, Vinka Foretića, Andru Jutronića i Marijana Mašiku. ${ }^{136} S$ druge strane,

129 Һ. МИЦИЋ, „Стотину вам богова”, 131. Ta knjiga je zabranjena 1922. u Zagrebu.

${ }^{130}$ Kritika 2/1921., br. 9-10. Urednici Kritike bili su Milan Begović i Ljubo Wiesner.

131 Zenit, 1/1921., br. 9, 13.-14.

132 Kritika 2/1921., br. 11-12, 453. U narednim brojevima Kritika Micića naziva „Ludomir Micić”, a njegov časopis „Kretenit”. Satisfakciju za uvredu Micić nije dobio ni na sudu, jer je presuđeno da je u pitanju - štamparska greška. Videti: Kritika 3/1922., br. 2, 96.; Kritika 3/1922., br. 8-9, 407.

133 Micić se tada sukobio i sa grupom srpskih književnika, a i sa jednim Englezom. Pismom od 6. XI 1921. Miloš Crnjanski, Stanislav Vinaver, Boško Tokin, Rastko Petrović, Stanislav Krakov, Dušan Matić i Alec Brown vrlo grubo prekidaju svaku saradnju s Micićem. Videti: Kritika 2/1921., br. 11-12, 452. Zenit, br. 10, 1/1921., 14.

134 Radićeva izjava iz 1923. glasila je: „Pre smo bili avangarda evropske kulture, a sada nastoje da budemo arijegarda balkanske nekulture”. Smisao tvrdnje je u tome da su Hrvati degradirani i unazađeni ulaskom u zajedničku državu sa Srbima. Micića je to pogodilo u nerv, jer je njegova osnovna ideja bila ona o superiornosti Balkana nad Evropom. Druga Radićeva izjava, data sa položaja ministra prosvete 1926, glasila je: „Srbi su dobar narod, ali samo da ginu, a mi Hrvati imamo da stvorimo kulturu.” Micić je na to ponovo objavio svoj pamflet. Videti: Lj. MICIĆ, „Papiga i monopol 'hrvatska kultura”, 1.-2.; ISTI, „Папагај и монопол “хрватска култура”, Зенит, 6/1926., br. 39, 5.-9.

135 R. KONSTANTINOVIĆ, „Četiri pesnika”, 235.-236. Konstantinović kao da ne primećuje promenu u Micićevim stavovima, dramatično menjajne konteksta u kome on deluje, niti uticaj društvenih i političkih promena na njega.

136 Videti katalog: V. HORVAT-PINTARIĆ, Josip Seissel, bez paginacije. Autorka tu, kao „vrlo važne” za stavove i slikarstvo J. Seissela, pominje delatnost Zenita i Lj. Micića, kod koga je Seissel prvi put video neka dela avangardne umetnosti i iz čijeg je časopisa svojevremeno crpao ideje i inspiraciju. To svoje viđenje Micića Horvat Pintarić je kasnije potpuno revidirala, tako da, prema njenoj novoj interpretaciji, Micićeva uloga u avangardi dvadesetih godina oscilira od marginalne do destruktivne (a možda čak i kriminalne!). Videti: Vera HORVAT PINTARIĆ, Tradicija i moderna, Zagreb 2009., 381.-400. 
Micić je prema jugoslovenstvu gajio otvorenu netrpeljivost, baš kao i prema kapitalistima: „Smrt inspiracije / Jugoslavija (...) Kapitalisti su integralni Jugosloveni”. ${ }^{137}$ Razlog tome je vrlo sažeto obrazložio 1926. godine:

1918. Srbija se propinje iz mučnog rata kao troglava aždaja: SHS. Na jednoj strani omamljeni pobednici, na drugoj strani prestravljeni pobeđeni. Obe strane su u znaku lažne ljubavi i pritajene mržnje. (...) 1919. U životu, osim šibera i ratnih bogataša, na svačijem licu poratni grčevi. Sve što mrzi Srbe i Srbiju postaje 'boljševik'. Kao vatra i ulje mešaju se pobeda i poraz - u jednoj državi. To se je zvalo jugoslovenstvo. ${ }^{138}$

Micić je 1938. na francuskom jeziku objavio roman Barbarogenije decivilizator, u kome oštro kritikuje jugoslovenski državni koncept i politiku kulturne unifikacije. ${ }^{139}$ „Izgubljena ideja" za kojom glavni junak romana traga od prvog poglavlja je ideja o Srbiji kao nacionalnoj državi, što jasno pokazuje kada govori o „Srbiji zvanoj Jugoslavija” ${ }^{140}$ Protivnici glavnog junaka i Micićevog alter ega - Barbarogenija - jesu „Jugosloveni”, tj. oni koji „kao neodređeni pol privlače ceo svet da radi protiv srpskog duha zemlje, jugoslovenska bezličnost ih tera da deluju protiv samih sebe." ${ }^{41} \mathrm{Na}$ drugim mestima Micić svoje nezadovoljstvo i gnev upravlja prema „hrvatskoj pulitici”, kojoj zamera da je „politika ucene, kleveta, nepristojnih uvreda", da uključuje represiju, konspiraciju, prezir i da predstavlja produžetak austrougarske politike prema Srbiji i Srbima. ${ }^{142}$ Ta autobiografska knjiga je neskriveno politički obojena i polemički intonirana. Poslednje što je Micić objavio bio je časopis karakterističnog naslova Srbijanstvo, čiji prvi i jedini broj je izašao maja 1940. godine. List se skoro u potpunosti sastoji od Manifesta Srbijanstva - programa srpskog nacionalizma shvaćenog na Micićev način. ${ }^{143}$ Prema onome što je Micić kasnije pričao, a drugi zabeležili, moglo bi se zaključiti da je on tokom rata (a i kasnije) bio simpatizer Draže Mihailovića, da je bio rojalista i da je, kada su međunarodni odnosi u pitanju, bio istrajni frankofil. ${ }^{144}$ Jedan od pouzdanih pokazatelja promene Mikčevih i Micićevih shvatanja je i pitanje jezika, tj. izgovora. Tokom dvadesetih godina Mikac je (kao i Micić) pisao ekavicom, a 1923. godine je čak prkosno tvrdio: „zenitizam je učvrstio ekavštinu, pošto je len prekapati Boranićev ijekavski pravopis." ${ }^{145}$ Neka Mikčeva pisma bračnom paru Micić pisana su ćirilicom. ${ }^{146}$ Međutim, posle sloma zenitizma, Mikac je 1935. na stranicama Nove Evrope polemisao sa Milanom Dimovićem, ovlašćenim državnim „korektorom” (i cenzorom) prevoda filmskih dijaloga, oko pitanja jezika kojim se titluju strani filmovi prikazivani u Jugoslaviji. Mikac se tada suprotstavio državnoj politici unifikacije jezika, zalažući se za nemešanje istočnog i zapadnog izgovora i leksike. ${ }^{147}$ Kasnije, tokom šezdesetih godina, kao politički emigrant, Mikac se

\footnotetext{
137 ๖. МИЦИЋ, „Стотину вам богова”, 131.

138 УРЕАНИШТВО ЗЕНИТА, „Фимм јеАног књижевног покрета”, [28.]

139 L. MITSITCH, Barbarogénie le décivilisateur, Paris 1938. Na srpskom izdato 1993.

140 ь. МИЦИЋ, Барбарогеније, 10.

141 Isto, 9.

142 Isto, 73.-78.

143 ๖. МИЦИЋ, „Манифест Србијанства”, Србијанство, 5.-23.

144 B. SKROBONJA, „Hasta la vista”, 3., 4., 8.

145 Videti: Z. DEROSSI, „Marijan Mikac”, 215.

146 NBS, LjMR/II/2. Pismo Mikca Auški Micić, Petrinja 25. 1. 1927.; Pismo Mikca Lj. Miciću, Petrinja 26. 1. 1927.; Pismo Mikca Lj. Miciću, Karlovac 4. 2. 1927.; Pismo Mikca Lj. Miciću, Petrinja 17. 2. 1927.; Pismo Mikca Anuški Micić, Petrinja 3. 3. 1927.; Pismo Mikca Lj. Miciću, Petrinja 8. 3. 1927.

147 Videti polemiku: Маријан МИКАЦ, „Фиммски преглед: језик у филмским текстовима”, Нова Европа, 16/1935., br. 2, 60.-63.; Миман АИМОВИЋ, „Фиммски преглеА: ‘Језик у фиммским текстовима”, Nova Evropa, 16/1935.,
} 
„zalaže za čisti hrvatski jezik, ističe njegovu samosvojnost i na primjerima dokazuje razliku između hrvatskoga i srpskoga jezika". ${ }^{148}$ Prema mišljenju istoričarke književnosti Zlate Derossi, Mikac je, pišući članak Hrvatski jezik u opasnosti, bio „potpuno na liniji” koju su zastupali autori Deklaracije o hrvatskom jeziku. ${ }^{149}$ Micićeva jezička evolucija se takođe može pratiti. Već u prvom broju Zenita on piše ekavicom, iako još uvek koristi i neke izraze karakteristične za zapadnu jezičku varijantu, a do 24 broja u svom časopisu koristi i latinicu i ćirilicu. Od prelaska u Beograd i 25 broja Zenita, svi tekstovi su na ćirilici i ekavici, osim onih na zapadnoevropskim jezicima. Prilikom ponovnog i demonstrativnog objavljivanja teksta „Papagaj i monopol 'hrvatska kultura” Micić je dodao napomenu: „sa hrvatskog na srpski preveo autor". ${ }^{150}$ Prevodeći početkom tridesetih godina Paramaunt-ove žurnale na srpski, Micić je insistirao na ekavici, što je Mikac prokomentarisao rečima: „Inače uživam kako vješto izbjegavate ijekavštinu, gdje je to moguće." ${ }^{151}$ Pred rat su međunacionalni odnosi bili već toliko zatrovani da su još jedino osporavanje državnog jedinstva i kulturne bliskosti dva naroda bile tačke oko kojih su srpski i hrvatski intelektualci bili saglasni. Ili bar neki od njih...

Antisemitizam. U „satiričnom romanu” Doživljaji Morica Švarca, koji je Mikac objavio 1937. u Zagrebu, mogu se uočiti brojni stereotipi o Jevrejima. ${ }^{152}$ Mikac u svom romanu pohlepu, srebroljubivost i egoizam pripisuje Jevrejima kao kolektivnu osobinu. To je naročito izraženo u epizodi kada se Moric Švarc naglo obogatio, pa počnu da ga saleću razne jevrejske organizacije, tražeći od njega novac i želeći da ga učlane u svoje redove: od „židovske bogoštovne općine” koja mu je „popedesetorostručila porez”, do cionista i Društva za odbranu od antisemitizma. ${ }^{153}$ Glavi junak je predstavljen kao tipični njujorški siromašni Jevrejin, čiji izgled predstavlja kompletnu karikaturu: on ima „duge, mršave ruke. Njegovo lice je takođe mršavo, duguljasto, usta ima mala, usnice bezbojne i uske, oči nelijepe, sitne, ali one škilje lukavo. Zbog uistinu malih dimenzija glave i pojedinih njenih dijelova, Moricov uistinu veliki nos izgleda još veći." ${ }^{154}$ U romanu Mikac „navodi” odlomke iz nacističkog priručnika o tome kako prepoznati „Židova” i u čemu se on razlikuje od „Arijevca”:

Usnice Židova su veoma često naduvene. Donja usnica je obješena. Izbočene oči su navodno karakteristika Židova. Očne vjeđe izgledaju pune i teške... Uši su velike, mesnate i otskaču od glave... „Židovski nos” se prepoznaje po tome, što mu je vrh u obliku kuke savijen prema dolje, dok su mu strane podignute prema gore (...) Promatran sa strane, židovski nos „visi” sa lica. (...) Kod Židova i židovskih miješanaca često upada u oči žućkasto-mrka put. Kosmatost je općenito velika, pa i rastenje brade. Zato su im obrve često sastavljene. Kosa često strši u

br. 3, 83.-86.; Маријан МИКАЦ, „Фиммски преглеА: Још мало о језику фиммских текстова”, Нова Европа, 16/1935., br. 4-5, 140.-146.; I. ŠKRABALO, 101 godina filma u Hrvatskoj, 101.-102.; Z. DEROSSI, „Marijan Mikac”, 215.-216.

148 Z. DEROSSI, „Marijan Mikac”, 216.

149 Videti: Isto, 216; Deklaracija o nazivu i položaju hrvatskog književnog jezika, Zagreb 1997. Derossi u svom članku, na str. 216, piše da je navedeni Mikčev tekst objavljen 1966, a u bibliografiji navodi da je to bilo 10. 4. 1968. Verovatno je 1968. tačna godina.

150 Ь. МИЦИЋ, „Папагај и монопол “хрватска култура”, 5.-9.

151 NBS, LjMR/II/2. Mikčevo pismo Miciću, Zagreb, 14. 11. 1933.

152 Autor je na početku knjige „prebrojao” Jevreje u Americi (4,5 miliona) i Njujorku (1,7 miliona), „konstatovao” da prezime Švarc ima njih 31.822 i da se od tog broja njih 1.745 zove Moris. Time je glavnog junaka predstavio kao tipičnog predstavnika jevrejskog naroda. M. MIKAC, Doživljaji M. Švarca, 11.

153 Isto, 48.-49.

154 Isto, 13.-14. 
sredini čela kao šiljak (Mefisto!) [...] Boja kose najčešće je smeđa ili crna. (...) Govor Židova (ćifutarenje). [...] Da se Židova često prepoznaje po govoru uči nas radio. 155

Stigavši iz Amerike u nacističku Nemačku Moric Švarc je saznao razne stvari o sebi i svojim sunarodnicima:

Jedan arapski učenjak je napisao, prije osam i po stoljeća, da su Židovi, iako razbacani po čitavom svijetu, međusobno čvrsto povezani, i da su ljudima neprijateljska i opasna stvorenja, s kojima treba postupati kao s otrovnim zmijama: odmah im zgaziti glavu (...) Muhamed je Židove uporedio s divljim životinjama. On kaže: „Zar divlje životinje koje žderu ljude, ne biste odmah ubili, i kad bi bile slične ljudima? A zar su Židovi nešto drugo nego žderači ljudi?” „Čovjeka čudi mržnja i prezir što ih svi narodi pokazuju prema Židovima. To je neizbežna posljedica njihovog postupanja!” To su Voltaire-ove riječi. „Židovski narod od Mojsijeva vremena ide za lihvarenjem i ucjenjivanjem” - Veli Napoleon Prvi. ${ }^{156}$

Nasuprot Mikčevim „duhovitostima” na račun Jevreja, o Micićevoj otpornosti na tu vrstu predrasuda najviše govori činjenica da je njegova supruga Anuška bila jevrejskog porekla - u devojaštvu se prezivala Kon. ${ }^{157}$ Postavlja se pitanje: da li je Mikac znao da je ona Jevrejka? Moguće je da nije. Šta se 1938. godine dogodilo između njih dvojice ne može se rekonstruisati, ali ostaje činjenica da je prepiska potpuno presahla posle objavljivanja knjige Doživljaji Morica Švarca. S obzirom na opštepoznatu Micićevu privrženost supruzi, sigurno je da mu se Mikčev roman nikako nije mogao svideti. S druge strane, ako je krajem tridesetih Mikac gajio simpatije prema nacizmu, zašto je još uvek održavao prijateljstvo sa Micićem, u to vreme deklarisanim frankofilom i srpskim nacionalistom? Moguće je da je gajio sentimente prema lideru zenitizma kao ličnosti, a ne kao predstavniku određene nacije ili neke ideologije. Uostalom, i Hitler je imao svog omiljenog Jevrejina, a da to nije promenilo njegove ideološke stavove. ${ }^{158}$ Odnos prema Jevrejima je, nesumnjivo, tema oko koje su Micić i Mikac imali sasvim različita shvatanja.

Fašizam, nacizam, ustaštvo. Kada je 1983. godine u beogradskom Narodnom muzeju bila otvorena izložba Zenitizam i avangarda dvadesetih godina najviše se, u duhu vladajuće ideologije i tekuće politike, govorilo i pisalo „o Micićevom nacionalizmu, rasizmu i fašizmu”. ${ }^{159}$ Tačno je da je Micić pre rata zastupao stav o kulturnoj „misiji” ruskog i srpskog „barbarogenija” u Evropi, ali njegov Zenit je bio mešovita grupa, srpska i hrvatska, sa kojom su sarađivali brojni stranci, Rusi, Francuzi, Italijani, Nemci, Česi, Mađari i brojni drugi. ${ }^{160} \mathrm{Ne}$ bi se moglo reći da je Micić tada gajio nacionalnu distancu, a pogotovo ne da

\footnotetext{
155 Isto, 59.-60. Naglašene reči: Marijan Mikac.

156 Isto, 123.

157 В. ГОАУБОВИЋ - И. СУБОТИТ, Зенит, 344.-345; В. DONAТ, „Performans kao oblik komunikacije hrvatske $D A D E^{\prime \prime}, 8$.

158 Hitlerov najbolji prijatelj Emil Moric (Maurice, 1897-1972) bio je unuk francuskog Jevrejina Šarla Morisa Švarcenbergera (Charles Maurice Schwartzenberger, 1805-1896). To se otkrilo 1935, kada je esesovac i Hitlerov telohranitelj Moric pokušao da se oženi, a prema rasnim zakonima je morao da dokaže „čistotu” porekla. Afera je izbila u javnost i Mikcu dala ideju za zaplet romana u kome glavni junak, američki Jevrejin, uzima lažni nemački identitet: Maurice Švarcenberg iz Alzasa. Videti: M. MIKAC, Doživljaji M. Švarca, 67.; Anna Maria SIGMUND, Des Führers bester Freund: Adolf Hitler, seine Nichte Geli Raubal und der "Ehrenarier" Emil Maurice - eine Dreiecksbeziehung, München 2003.

159 Na ideološke i političke diskvalifikacije Micića u svom otvorenom pismu gradonačelniku Beograda, Bogdanu Bogdanoviću, ukazala je Irina Subotić. Videti: И. СУБОТИЋ, „Зенит и авангарда”, 6.

160 В. ГОАУБОВИЋ - И. СУБОТИЋ, Зенит, 19.
} 
je bio fašista. Kada je 1926. ušao u Rijeku, Micić je bio uhapšen i zatvoren od strane fašističke policije, odakle se, ponižen i ljut, izbavio zahvaljujuću pomoći T. F. Marinetija. ${ }^{161}$ Verovatno je to poznanstvo sa italijanskim futuristom poslužilo kao osnova za kasnije povezivanje zenitizma sa fašizmom. Međutim, Micićeva izuzetno razvijena mreža kontakata širom Evrope uključivala je razne osobe, koje su kasnije imale vrlo različite životne puteve. Marinetijev fašizam, Mikčevo ustaštvo, Skerlov komunizam (a kasnije nedićevstvo) ili boljševizam Majakovskog, sami po sebi ne govore ništa o Miciću, osim da je bio sagovornik svim tim ljudima. Vremenom, ideologije koje su posle Prvog svetskog rata obećavale društveni i moralni preporod, pokazale su svoje destruktivne potencijale. Micić je to razumeo. U svom romanu iz 1938. on kaže:

(...) fašizam, kao i njegov stariji dvojnik komunizam, predstavlja samo atak na zdravlje Evrope. (...) Najzad, fašizam (na latinskom) nije ništa nego boljševizam (na slovenskom) pripremljen sa italijanskim sosom. (...) Nemačka takođe radi na dolasku fašizma, zvanog nacionalsocijalizam, tojest nemački boljševizam. ${ }^{162}$

Pronicljivo opazivši srodnost tih ideologija i definišući to kao „tiranija”, Micić je zapečatio svoju sudbinu kada komunisti budu došli na vlast u Jugoslaviji. ${ }^{163}$ Mikčev odnos prema modernim diktaturama bio je manje teorijski i sintetičan, a više konkretan i praktičan naročito u odnosu na nacizam. Šta je do toga dovelo teško je reći. U međuvremenu su se dogodili atentati na Stjepana Radića i kralja Aleksandra, ali Mikac u prepisci ne pominje te događaje. Tek, njegovo novo pojavljivanje na književnoj sceni predstavlja ga u bitno drugačijem svetlu. U svom romanu Doživljaji Morica Švarca Mikac iznosi podatke o raznim oblicima nacističkog progona Jevreja, ali to predstavlja kao jevrejsku propagandu. U knjizi, na protestnom skupu Jevreja u Njujorku, do detalja se opisuju razni oblici nacističkog terora nad Jevrejima: koncentracioni logori, ubistva i ozlede, fizička i psihička mučenja, šikaniranja i premetačine, isterivanje s posla, bojkot, zabrana raznih delatnosti... ${ }^{164}$ Otišavši u „Hitlerovu Nemačku”, Švarc je želeo da potvrdi takvu sliku, kao i da ispuni „visok, uzvišen cilj: da se baci rukavicom na cijeli hitlerovački režim (...). Ali, pored svih napora, još nije doživio ništa značajno! Hitlerovi vojnici, 'smeđe košulje', SA-odjeljenja, i 'crna garda', SSodjeljenja, ili su nevino marširali gradom, svirajući, pjevajući i zviždeći, ili su mirno pili svoje pivo, ili sa svojim porodicama i prijateljima, obijesno raspoloženi, išli u šetnju..." ${ }^{165}$ Američki Jevrejin u Nemačkoj „(u) bolesnom očekivanju nereda, skandala, počeo je izazivati. Umjesto da čeka svoj red, počeo se prije drugih penjati u autobuse, ali dočekao je samo to, da bi mi netko od ostalih putnika - muško, žensko - doviknuo: 'Natrag! Naučite što je red!' i grubo ga - punim pravom, uostalom - udario u rebra." ${ }^{166}$ Ništa od strahota za koje je čuo u Americi i koje je očekivao Švarc nije video, ali je bilo mnogo povoda da se „uveri” u moralnost, plemenitost, humanost i organizacionu superiornost Nemaca. Najupečatljivija scena, osmišljena da potpuno razoruža Švarca, a i čitaoca, je kada „gorostasni”, hrabri i skromni pripadnik SA odreda, rizikujući svoj život, skače pred tramvaj u pokre-

\footnotetext{
161 §. МИЦИЋ, Барбарогеније, 92.-100.; В. ГОАУБОВИЋ - И. СУБОТИЋ, Зенит, 349.

162 ๖. МИЦИТ, Барбарогеније, 98.-99.

163 Isto, 105; 3. МАРКУШ, Зенитизам, 37.-38.

164 M. MIKAC, Doživljaji M. Švarca, 50.-51.

165 Isto, 111.

166 Isto, 112.
} 


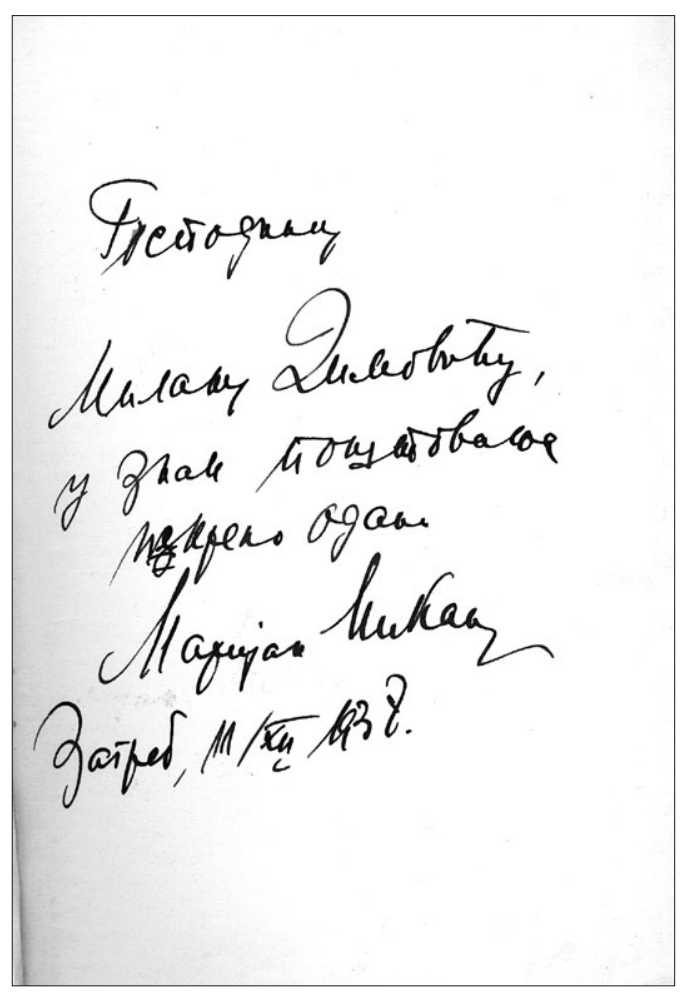

Slika 4. Mikčeva posveta Milanu Dimoviću u knjizi Doživljaji Morica Švarca u Hitlerovoj Njemačkoj, Zagreb, 11. prosinca 1938. tu da bi spasao nečije kučence. ${ }^{167}$ Stvorena je slika da je neko oklevetao naciste (jasno je i ko!), a tadašnji nemačko-jevrejski odnosi u romanu se objašnjavaju kao posledica borbe za prevlast između ta dva naroda. Ali, Jevrejima se nudi izlaz iz nezavidne situacije u kojoj se tada nalaze:

Ključ, koji će zatvoriti ili otvoriti vrata sporazuma, nalazi se u rukama Židova, ma gdje oni živjeli! Židovi mogu svojim životom i radom, poštenim i nesebičnim, pokazati, da nemaju pravo oni, koji ih mrze i napadaju. Tada žaoka prelazi sa cjeline na pojedinca. Kakav tko jest, tako bi trebalo prema njemu i postupati. Tada bi se nemoćno srušile sve teorije. ${ }^{168}$

Prividna „ubedljivost” i „pravednost” navedenog „rešenja”, koje, u stvari, implicira jevrejsku „krivicu” i „odgovornost” za njihov progon, trebalo bi u čitaočevim očima da pojača to što ga izgovara jedna (prikrivena) Jevrejka, „madame Jenny”. Knjiga se završava potpunim porazom Morica Švarca - Nemci, a posebno „hitlerovci”, pokazali su se neuporedivo boljim od njegovih predrasuda o njima, a nacista Hans Miler (Müller) ga je čak oženio svojom ćerkom, berlinskom lepoticom! Knjigu takvog sadržaja Mikac je tada plasirao kao „satiričan roman”. Međutim, radi se o „satiri” čija žaoka je uperena, pre svega, protiv Jevreja kao naroda. U vreme kada se knjiga pojavila progon Jevreja i Nemačkoj je uveliko trajao i nije bio tajna ni za koga, pa ni za Mikca. Ima mišljenja da je Mikčeva „pozicija u odnosu na pravo stanje... suviše benigna i relativistička, ali u času pisanja romana nije bila nipošto povijesno, a još manje literarno lažna." ${ }^{69}$ Međutim, nije stvar u tome da li je autorova „pozicija lažna”, već kakva su njegova ideološka shvatanja i političke tendencije. Nije Mikac bio „na samom rubu antisemitizma” ${ }^{170}$ kako se blagonaklono smatra, nego je on taj rub i prešao, a njegova naklonost nacizmu je van sumnje. To potvrđuju reakcije Jevrejske zajednice na tu knjigu, a i njena zabrana koja je usledila. ${ }^{171}$ Činjenica da je roman zabranjen Mikca nije sprečila da ga poklanja svojim poznanicima. ${ }^{172}$

67 Isto, 116.-117.

168 Isto, 152.

169 Oko ove ocene saglasni su B. Donat i Z. Derossi, koja citira Donatov članak o Mikcu. Videti: Z. DEROSSI, „Marijan Mikac", 183.

170 Isto.

171 Reagovao je zagrebački list Židov, 22/1938., br. 12, 9.; Z. DEROSSI, „Marijan Mikac”, 183.

172 Primerak koji se čuva u NBS nosi posvetu: „Milanu Dimoviću, u znak poštovanja iskreno odani Marijan Mikac, Zagreb 11/XII 1938.” Posveta je napisana mesec dana posle „kristalne noći” - velikog pogroma Jevreja u Nemačkoj! 
Knjiga je bila zabranjena i u NDH, jer je Slavko Kvaternik pogrešno protumačio mišljenje Mikčevog lika Švarca kao autorov stav prema nacizmu. Nesporazum je brzo razrešen, a Mikac je kasnije tu epizodu tumačio kao dokaz da je NDH bila „tolerantna” i „demokratska". ${ }^{173}$ Micić se sa takvom ocenom nikako ne bi složio. Za njegov potpuni i konačni gubitak nacionalne tolerantnosti presudan je bio pokolj Srba u NDH, naročito stravični zločin u njegovoj Glini, preko čega nikako nije ni mogao ni hteo da pređe ćutke. ${ }^{174}$ Takav stav je, međutim, bio u suprotnosti sa vladajućom ideologijom „bratstva i jedinstva”, koja je podrazumevala nepominjanje i zamagljivanje osetljivih i bolnih pitanja iz zajedničke prošlosti dvaju naroda. To je jedan od razloga za ideološku žestinu prilikom vrednovanja Micićevog dela u vreme socijalizma, ali i za Micićevu nepopustljivost i nepristajanje na ma kakvu saradnju sa institucijama novog režima. Nasuprot Micićevoj, o tadašnjoj Mikčevoj ideološkoj i političkoj poziciji dovoljno govori njegova bibliografija. Nije sporno što je napisao prvi roman na temu propasti NDH i sudbine njenih pristalica. Itekako je sporna kontinuirana saradnja u Luburićevu časopisu Obrana. ${ }^{175}$ Časopis Obrana Mikac je pred kraj svog života i uređivao, nasledivši na tom položaju Vjekoslava Maksa Luburića. ${ }^{176}$

\section{Zaključak}

Iskreni saradnički i prijateljski odnosi Micića i Mikca počeli su posle Prvog svetskog rata, na talasu anarhičnog umetničkog entuzijazma i naraslih stvaralačkih ambicija pokrenutih Oktobarskom revolucijom, nastavili su se u ekonomski tegobnim i politički nemirnim godinama međuratnog perioda, sve do novog svetskog rata. Obojica su počeli svoje javno delovanje kao marginalci i provincijalci, koristeći nove okolnosti za društvenu i profesionalnu afirmaciju. Neobuzdana Micićeva ambicija da ostavi značajan trag u sferi kulture dobro se dopunjavala sa Mikčevom potrebom da u datom okruženju podigne svoj ugled i izdvoji se iz prosečnosti. Tako su došli do odnosa obožavanog lidera i odanog sledbenika, iako se nisu u svemu slagali, a naročito ne u odnosu na jugoslovenstvo. Slom zenitističkog pokreta i gašenje Zenita izvukli su im tlo pod nogama, a politički potresi u Evropi, posebno rađanje totalitarnih pokreta i država i drugih diktatorskih režima radikalizovali su politički, kulturni i društveni ambijent u Jugoslaviji. Iako tokom tridesetih godina Micić i Mikac održavaju dobre lične odnose, obojica se menjaju, pomerajući svoje stavove sve više i više udesno - ka šovinizmu. U to vreme, njihovo prijateljstvo opstaje uglavnom zato što su geografski vrlo udaljeni i komuniciraju prepiskom koja se odnosi isključivo na teme o kulturi i privatnom životu. Dalje zaoštravanje političke situacije u Evropi, bujanje totalitarnih ideologija i, pogotovo, početak i eskalacija Drugog svetskog rata, otvorili su provaliju između njih i uslovoli prestanak dalje saradnje i kontakata. Iz rata su dva nekadašnja prijatelja i saradnika izašla kao poraženi i odbačeni ljudi, ostrašćeni i netolerantni, svako sa svojim gubicima i svojim viđenjem zajedničke prošlosti, koja su imala malo toga zajedničkog.

$\overline{173}$ Z. DEROSSI, „Marijan Mikac”, 212.

174 Micić je znao da zameri poznanicima, jer nisu „javno osudili zločin u Glini”. Z. MARKUŠ, „Razgovori sa Ljubomirom Micićem, 4.", Odjek, 24/1971., br. 23, 29.

175 Npr: Marijan MIKAC, U povorci smrti. Roman iz hrvatske tragedije 1945, Chicago 1954.

176 Luburić je, na Mikčevu molbu, napisao pogovor Masučijevom dnevniku. Videti: Vjekoslav LUBURIĆ, „Pro domo sua", u: G. MASUCCI, Misija u Hrvatskoj, 289.-298.; Tko je tko u NDH, 271. 
Novom društvu koje je izgrađivano u Jugoslaviji oni ne samo da nisu bili potrebni - bili su potpuno suvišni. Bili su neprijatelji. Iako je zasad nerazjašnjeno pitanje do kada tačno je trajala komunikacija između Mikca i Micića, kao i pod kakvim tačno okolnostima je prestala, možemo se zapitati, posle svega, šta bi dva bivša prijatelja, da je „komedijant slučaj” udesio da se posle rata sretnu, mogli da kažu jedan drugome?

Najverovatnije - ništa...

\author{
$\cos$ \\ From Anarchism to Chauvinism: World War II and \\ Members of the Avant-garde. \\ Artistic Circle around the Zenit - Ljubomir Micić \\ and Marijan Mikac
}

The First World War had brought about numerous avant-garde art movements, which stemmed from the resistance that young intellectuals and artists felt towards the existing system of values and social structures which caused the war. The paper analyses the biographies and the changes in the ideological attitudes of two members of the Yugoslav avant-garde artistic group of Zenitists, Ljubomir Micić and Marijan Mikac. It looks into the consequences of political events and processes, and particularly the ways in which the political situation on the eve of World War II and its consequences, affected the relations between their two nations (the Serbs and the Croats), as well as their personal relationship. The first part of the paper deals with the relationship between Micić and Mikac through four main phases, which corresponded to stormy political changes in Europe: the period of zenitism (1921-1926), the period after zenitism and before the war in Yugoslavia (1927-1940), the wartime period (1941-1945) and the post-war period (1945-1972). The second part of the paper analyses the evolution of Micić and Mikac's ideological attitudes, by tracing the changes in those attitudes towards characteristic phenomena: revolution, anarchism, Marxism, bolshevism, communism, internationalism, nationalism, anti-Semitism, fascism, Nazism and the Ustashe movement. Research has shown that the political scene, both in Yugoslavia and abroad, had a crucial impact on the cultural scene, and particularly on two former friends, who ended their lives as irreconcilable enemies, rejected by society and far from each other, despite their common origins as supporters of the radical left.

Keywords: Zenitism, Ljubomir Micić, Marijan Mikac, Yugoslavia, World War II, anarchism, Marxism, internationalism, nationalism, anti-semitism, fascism 


\section{Izvori i literatura}

\section{Neobjavljeni izvori}

Jevrejski istorijski muzej, Beograd, Kartoteka članova.

Narodna biblioteka Srbije, Beograd, Ljubomir Micić, rukopisi.

\section{Objavljeni izvori}

Вилијам АБРАМЧИК, [Велимир Абрамовић], „Кьуч за европеизацију Балкана”, Кғыжсевне новине (БеограА), br. 664, 10. 2. 1983., 35.-36.

Irina ALEKSANDER, Svi životi jedne ljubavi, Zagreb 2003.

Теодор АНЋЕ АИЋ, „За балканизацију Европе”, НИН (Beograd), 13. 2. 1983., 32.-33.

Радивој ЦВЕТИЋАНИН, „Утаја ‘србијанства', случајно или не”, Недељна борба (Beograd), 19.-20. 2. 1983., 11.

Милан АИМОВИЋ, „Фиммски преглед: 'Језик у фиммским текстовима”, Nova Evropa (Zagreb), 16/1935., br. 3, 83.-86.

Momčilo ĐORGOVIĆ, „Barbarogenij još jednom”, Danas (Zagreb), 2/1983., br. 55, 63.-64.

Видосава ГОАУБОВИЋ, „Из преписке око Зенита и зенитизма”, Љетопис Сриског културног друитва „Просвјета” (Загреб), 4/1999., 277.-293.; 5/2000., 231.-258.; 6/2001., 237.-256.; 7/2002., 178.-204.; 8/2003., 305.-318.

Видосава ГОАУБОВИЋ, „Преписка између Маријана Микца и Фубомира Мицића”, ьетопис Српског културног друитва „Просвјета” (Загреб), 9/2004., 400.-408.; 10/2005., 369.383.

Vera HORVAT-PINTARIĆ, Josip Seissel, Zagreb 1978.

Zoran MARKUŠ, „Razgovori sa Ljubomirom Micićem 1-4”, Odjek (Sarajevo), 24/1971., br. 2023.

Zoran MARKUŠ, „Što je želio Micic”, Danas (Zagreb), br. 55, 8. 3. 1983., 40.

Giuseppe MASUCCI, Misija u Hrvatskoj 1941-1946, Madrid 1967.

ьубомир МИЦИЋ, Антиевропа, БеограА 1926.

Бубомир МИЦИЋ, Барбарогеније дечивилизатор, БеограА 1993.

ьубомир МИЦИЋ, „Стотину вам богова”, Авангарда. Свеске за теорију и историју книжсевно/ уметничког експеримента, 2/1998.-2000., br. 2-4, БеограА 2001., 138.

Ljubomir MICIĆ - Ivan GOLL - Boško TOKIN, „Manifest zenitizma”, Авангарда. Свеске за теорију и историју книлкевно/уметничког експеримента, 2/1998.-2000., br. 2-4., Београд 2001., 117.-119.

Borislav MIHAJLOVIĆ, Autobiografija o drugima, II, Novi Sad 2003.

Marijan MIKAC, Doživljaji Morica Švarca u Hitlerovoj Njemačkoj, Zagreb 1937.

Маријан МИКАЦ, „Филмски преглеА: језик у филмским текстовима”, Нова Евроnа (Zagreb), 16/1935., br. 2, 60.-63.

Маријан МИКАЦ, „Филмски преглеА: Још мало о језику филмских текстова”, Нова Европа (Zagreb), 16/1935., br. 4-5, 140.-146.

Marijan MIKAC, Tri godine rada Hrvatskog slikopisa, Zagreb [1944.]

Маријан МИКАЦ, „Зенитистичка нова уметност”, Авангарда. Свеске за теорију и историју книжевно/уметничког експеримента, 2/1998.-2000., br. 2-4, Београд 2001., 162.-164.

В. И. АЕНИН, Полное собрание сочинений, Том 28, (Тетради по империализму), Москва 1962. 
Rade LEPOSAVIĆ, „DADA Clipping. Traganje za izgubljenim srpskim (?) dadaistom”, New Moment (Beograd), 15/2001.

Mirko LUKAVAC, „Prvi dani kinematografje u SR Hrvatskoj (1945-1946)” Filmska kultura (Zagreb), 19/1975., br. 100, 163.-167.

Branislav SKROBONJA, „Hasta la vista ili priča o Miciću”, New moment (Beograd), 4/1995., 2.24.

Ирина СУБОТИТ, „Сећања на сусрете са Љубомиром Мицићем”, Книжевност (БеограА), 37/1981., br. 7-8, 1483.-1488.

Irina SUBOTIĆ, Zenit i avangarda 20ih godina (katalog izložbe), Beograd 1983.

Ирина СУБОТИЋ, „Зенит и авангарда”, Книжевне новине (БеограА), br. 669, 28. 4. 1983., 6.

Р[адован] ПОПОВИЋ, „Мицић и његов зенитизам”, Политика (БеограА), br. 24924, 25. 2. 1983., 10.

Стеван СТАНИЋ, „Између 'србијанства' и космополитизма” (интервју са Богданом Богдановићем), НИН (Београд), br. 1682, 27. 3. 1983., 27.-30.

\section{Štampa}

Kritika (Zagreb), 1921.-1922.

Политика (Beograd), br. 6669, 17. 11. 1926., 6. (http://scc.digital.nb.rs/collection/politika)

Србијантво. Книжевно-политички часопис (Beograd), 1/1940., br. 1.

Zenit (Zagreb-Beograd), 1921. -1926. (http://scc.digital.nb.rs/collection/zenit)

\section{Literatura}

Balkan Strongmen: Dictators and Authoritarian Rulers of South Eastern Europe, (ur. Bernd J. Fischer), London 2007.

Mira BOGDANOVIĆ, „Jugoslavenski disidenti i hladni rat”, Sociologija, 6/2009., br. 2, 113.-136.

Deklaracija o nazivu i položaju hrvatskog književnog jezika, Zagreb 1997.

Zlata DEROSSI, „Marijan Mikac, (Senj 29.1.1903.-Atlantik kod Cape Towna 16.3.1972.)”, Senjski zbornik, 24/1997., br. 24, 169.-226.

Branimir DONAT, „Performans kao oblik komunikacije hrvatske $D A D E$ i njenih inačica s javnošču”, Dani Hvarskoga kazališta. Grada i rasprave o hrvatskoj književnosti $i$ kazalištu, 30/2004., br. 1, 5.-12.

Branimir DONAT, „Zaboravljeni i nepoznati Marijan Mikac”, Kolo Matice hrvatske, 3/1993., br. 9-10, 711.-737.

Luka DOTLIĆ, „Sporovi Ljubomira Micića”, Polja (Novi Sad), 17/1971., br. 152, 4.-5.

Fransoa FIRE, Prošlost jedne iluzije. Komunizam u dvadesetom veku, Beograd 1996.

Aleksandar FLAKER, Ruska avangarda, Zagreb 1984.

Видосава ГОАУБОВИЋ - Ирина СУБОТИЋ, Зенит 1921-1926, БеограА 2008.

Eric HOBSBAWM, „Socialism and the Avant-Garde, 1880-1914”, Uncommon People. Resistance, Rebellion and Jazz, London 1998., 171.-186.

Vera HORVAT PINTARIĆ, Tradicija i moderna, Zagreb 2009.

Radomir KONSTANTINOVIĆ, „Četiri pesnika”, Treći program (Beograd), 4/1972., zima, 175.349. 
Radomir KONSTANTINOVIĆ, „Ko je barbarogenije”, Treći program (Beograd), 1/1969., proleće, 9.-21.

Stephen LEE, European dictatorships 1918-1945, London - New York 2000.

Зоран МАРКУШ, Зенитизам, БеограА 2003.

Goran MILORADOVIĆ, „Ljudi na strateškim mestima: uzroci, posledice i smisao sukoba Josipa Broza Tita i Milovana Đilasa na Trećem (vanrednom) plenumu CK SKJ 1954. godine”, Tito viđenja i tumačenja, (zbornik radova), Beograd 2011., 199.-231.

Горан МИАОРААОВИЋ, „Аомаћи тримери у иностраној режији: Обавештајне и саботерске активности против југословенске кинематографије 1945-1955. године”, Годишььк за друштвену историју (Beograd), 17/2010., br. 1, 67.-88.

Горан МИАОРААОВИТ, Аепота под надзором. Совјетски културни утичаји у Југославији 19451955, БеограА 2012.

Андреј МИТРОВИТ, Време нетрпељивих. Политичка историја великих држава Европе 19191939, ПоАгорица 1998.

Предраг ПАААВЕСТРА, Историја модерне српске књижевности, БеограА 1986.

Миодраг ПРОТИЋ, Српско сликарство ХХ века, БеограА 1970.

Miodrag PROTIĆ, Treća decenija. Konstruktivno slikarstvo, Beograd 1967.

Ivo ŠKRABALO, 101 godina filma u Hrvatskoj 1896.-1997.: Pregled povijesti hrvatske kinematografije, Zagreb 1998.

Борис ВРГА, „Зенитистичке вечерње у Петрињи”, Һетопис Српског културног друштва „Просвјета” [Загреб], 10/2005., 384.-391.

Радован ВУЧКОВИТ, Модерни правии у кьижевности, Београд 1986. 